\title{
The United States Response to Common Market Trade Preferences and the Legality of the Import Surcharge
}

Since 1934 the United States has attempted to maintain "mostfavored nation" treatment as an organizing principle for world trade. ${ }^{1}$ This principle, which requires that countries preserve a unitary external tariff for the same goods imported from different countries, has been given legal status under domestic statutes ${ }^{2}$ and the General Agreement on Tariffs and Trade (GATT). ${ }^{3}$

Since the formation of the European Economic Community (ECG) or Common Market in 1958, however, a major challenge has been posed for the most-favored nation principle. The EEG has gone outside the six original Common Market countries to conclude a number of association agreements, generally with less-developed countries, in which the parties set tariff levels on particular goods at a rate lower than those set for the rest of the world. ${ }^{4}$

This comment is organized into two principal parts. The first part

1 H. Catudal, The General Agreement on Tariffs and Trade: An Article-by-Article Analysis in Layman's Language 4 (U.S. Dep't of State Commercial Policy Series No. 179, 1961). In practice the United States has made certain exceptions. G. PATTERson, Discrimination in International Trade: The Policy Issues 1945-1965, 14-15 \& n.20 (1966).

2 Trade Expansion Act of 1962, 19 U.S.C. $\$ 1881$ (1970). Before 1962 the principle was stated in Act of June 2, 1934, ch. 474, § 350(a), 48 Stat. 943.

3 The original version is the General Agreement on Tariffs and Trade, Oct. 30, 1947, 61 Stat. pt. 5, at All (1947), T.I.A.S. No. 1700, 55 U.N.T.S. 194. The current version appears in 4 GATT, Basic INSTRUMENTS AND SELECTEd Documents (1969). The current version of the Agreement will hereinafter be cited as GATT. The "most-favored nation" principle appears in article $I$.

1 These agreements derive their legal status within the EEC from three separate provisions of the Treaty of Rome. Treaty Establishing the European Economic Community, Mar. 25, 1957, 298 U.N.T.S. 11. Articles 131-36 and the Implementing Convention establish the Association of Overseas Countries and Territories, which is limited to the overseas dependencies of the EEC. Article 238 establishes the framework for "assaciation agreements" for countries unwilling to incur the obligations of full membership or unable to do so because of location or political considerations. And articles 111-14 authorize commercial agreements covering one or more products with other countries. See Note, Trade Preferences for Developing Countries: Options for Ordering International Economic and Political Relations, 20 STAN. L. REv. 1150, 1151-52 (1968). 
examines the elements of a typical EEC agreement which are of concern to the United States and details the expansion and impact of such agreements from the formation of the EEC until the present. It concludes with the principal responses of the United States to the development of the EEC trade preference system: challenges under the GATT; acceptance of the "general preference" alternative, whereby all developed countries jointly grant preferences to all less-developed countries; and negotiation of its own preferences, principally with Latin America.

The second part analyzes the policy and legal questions raised by the recent imposition by the United States of the ten percent surcharge, concluding that the act exceeded the President's statutory authority to raise tariffs. Unlike the other responses, which were specific to EEC trade preferences, the surcharge involved a much wider range of monetary and trade issues. Nonetheless, it encompassed the preference system and must be viewed, in part, as the last United States response.

Two general themes are stressed throughout. First, emphasis is placed on the evolution of American policy-the gradual erosion of adherence to the most-favored nation principle coupled with an increased willingness to adopt protectionist policies, if only to encourage dismantling of the EEC's special preference system. Second, the significance of the preference issue is seen as going beyond the relationship of the United States and the EEG to the less-developed countriesinvolving, rather, the challenge that the emergent economic and political power of the EEC provides to the United States.

\section{Trade Preferences: Specific United States Responses}

\section{A. A Model of Association and Trade Preferences: The Nigerian Agreement}

The agreement between the EEC and Nigeria, negotiated in 1966 but never ratified due to the confusion caused by the Nigerian civil war, ${ }^{5}$ served as a model for later association agreements and illustrates the issues which they pose.

The agreement established two sets of preferences. First, Nigeria was

5 Agreement Establishing an Association Between the European Economic Community and the Republic of Nigeria, July 16, 1966, in 5 INT'c Lefal MAtERIALs 828 (1966) [hereinafter cited as Nigerian Agreement]. The intervention of the Nigerian civil war probably accounts for the failure of Nigeria to ratify. See W. Zarman, THE Politics of TRAdE Negotiations Between Africa and the European Economic Community 93 (1971). Certain EEC countries, particularly France, also had objections. Id. at 89. See also van den Bergh, The New Convention of Association with African States, 1 CoMM. MKT. L. REv. 156, 162-64 (1963). 
entitled to sell certain goods to EEC countries at a tariff rate below the common customs tariff (CCT), which all other importers into the Common Market must pay. ${ }^{6}$ Second, Nigeria granted reverse preferences to the EEC, which allowed all EEC countries to import goods into Nigeria at a rate below that paid by other third parties. ${ }^{7}$

The margins of preference granted by both parties were protected and limited.8 Thus, Nigeria was specifically prohibited from narrowing the EEC's margin of preference by lowering its external tariff on those goods subject to preferences. ${ }^{9}$ EEG protection to Nigeria was complicated by its participation in other association agreements which involved the same goods on which it was giving preferences to Nigeria. Thus, the EEC pledged only that Nigeria's commercial advantages would be at least equal to those enjoyed by the prior associates, the eighteen African states of the Yaoundé Convention..$^{10}$

The EEC limited the value of the preferences it granted by applying the quantitative restriction device to Nigeria's principal exports: cocoa beans, groundnut oil, palm oil, and semi-manufactured wood products. ${ }^{11}$ This device established a quota ceiling, below which Nigeria would pay the internal EEC duty (usually zero) that the Six pay in trade with each other, and above which Nigeria would pay the CGT rate. The quota ceiling itself was pegged to Nigeria's past volume of

6 Nigerian Agreement, supra note 5, tit. I, art. 2, and exceptions at Protocol No. 1. The tariff schedules for imports into the EEC appear in OfFICE OF THE SPECLAI. REPREsENTAtive for Trade Negotiations, Customs Tariff of the European Communities (1969) [hereinafter cited as CuSTOMS TARIFE].

7 Nigerian Agreement, supra note 5, tit. I, art. 3, and exceptions at Protocol No. 2.

8 Id. tit. V, art. 27.

$8 I d$. Annex IX, para. I provides that "[i] $]$ respect to the products contained in the schedule annexed to Protocol No. 2, the tariff advantages reserved for the Member States over third countries will not be reduced as long as the Agreement remains in force."

10 Id. Annex III. The Yaoundé Convention was an association agreement under article 238 of the Treaty of Rome with the following African States: Bwandi, Cameroons, the Central African Republic, Chad, Congo (Brazzaville), Congo (Leopoldville), Dahomey, Gabon, the Ivory Coast, Madagascar, Mali, Mauritania, Niger, Rwanda, Senegal, Somalia, Togo, and Upper Volta. The official French text of the agreement appears at 93 E.E.C. J.O. 1491 (1964).

11 Nigerian Agreement, supra note 5, Protocol No. 1. These products accounted for nearly 30 percent of the value of Nigeria's exports in 1964. GATT, DEvelopMENT PLAN Studies: The First Six Year Plan of Nigeria 21 (1966) [hereinafter cited as Six Year PLAN]. If palm kernels and groundnuts were also included, these products would comprise 66.7 percent of the total value of Nigerian exports in 1958 and 55.3 percent in 1964. Id.; P. ORIGBo, Africa aNd the Common Market 95 (1968). Since 1966 the structure of Nigeria's export trade has changed dramatically. By 1969 petroleum oil accounted for an increasing percentage of Nigeria's total exports. See 18 Nigeria Federal Office of STATISTICS, DIGEST, No. 4, at 52 (1969). Earnings from palm oil dropped substantially, from a monthly average of $£ N 916,000$ in 1966 to $£ \mathrm{NI} 2,000$ in 1969, while earnings from groundnut oil and cocoa continued steadily. $I d$, at 50 . 
exports of these goods to the EEC, which means that an expanded volume of production would not receive the preference benefits. ${ }^{12}$ Within the tariff quota, Nigeria received a sizeable advantage since the CCTs were 5.4 percent on cocoa beans, 14 percent on palm oil, 10-15 percent on groundnut oil, and 13 percent on semi-manufactured wood products. ${ }^{13}$

Nigeria attempted to limit its grant of preferences in two ways. First, it granted the lowest margin of preference-two percent-on items which had been supplied principally by third parties such as the United Kingdom..$^{14}$ Second, it granted an increasing preference over time on certain items. Thus, Nigeria would reduce its tariff to the EEG to zero over a three-year period on these goods, fifty percent upon initiation of the agreement and twenty-five percent in each of the two successive years. ${ }^{15}$

For the purpose of this comment, it is important to identify the two economic effects of this agreement and others like it which are of interest to the United States: trade creation and diversion ${ }^{16}$ and decreases in exports of nonassociated states.

Trade creation and diversion concerns whether a given preference tends to shift production to a lower- or higher-cost producer; the former "creates" trade and the latter "diverts" it. To the extent that the United States identifies its interests with the efficient allocation of world resources, it favors agreements which create trade and opposes

12 The ceilings were to increase gradually, but not significantly. In 1968 , when the last full-year quota was determined, the ceilings were 75,200 metric tons for cocoa beans, 7,300 metric tons for groundnut oil, 34,900 metric tons for palm oil, and 620 metric tons for specified wood products. Nigerian Agreement, supra note 5, Protocol No. 1, art. 3. The respective quantities of these products exported to EEC countries in 1964 were 78,000 metric tons of cocoa beans, 7,800 metric tons of groundnut oil, 36,000 metric tons of palm oil, and 6,000 metric tons of sawn timber (exact equivalents of woods named in agreement unavailable). P. OKIGBo, supra note 11, at 98 , Table 5.

13 These were the CCTs which applied after the Kennedy Round, which would have been applicable during the period the Nigerian Agreement was to be in effect. The Kennedy Round changed the rates only on cocoa beans and plywood, which had been nine and fourteen percent, respectively. 4 Contracting Parties to the GATT, Legal Instruments Embodying the Results of the 1964-1967 Trade Conference, Schedule XL, pt. I, Tariff Item Nos. 18.01, 44.15 (1967). The rates on palm and groundnut oils remained at the level previously negotiated. Contracting PARTIEs to the GATT, Protocol, to THE GeNerat Agrfement on TARiffs and Trade Embodying Results of the 1960-61 Tariff CoNFERENCE, Schedule XL, pt. I, Tariff Item No. 15.07 (1962).

14 P. OKIGBo, supra note 11 , at ch. 6 app.

15 Nigerian Agreement, supra note 5, Protocol No. 2, art. 1.

16 See generally K. Dam, The GATT: LAw and International Economic Organization 283-86 (1970); J. Viner, The Customs Union Issue 41-56 (1950); Dam, Regional Economic Arrangements and the GATT: The Legacy of a Misconception, 30 U. CHr. L. REv. 615, 625 (1963). 
those which do not. Moreover, an efficient allocation of world resources can be directly beneficial to American consumers. A shift in production to a higher-cost producer, on the other hand, may result in higher prices for imports. ${ }^{17}$

These principles can be illustrated by the preference that the EEC granted to Nigeria on cocoa. ${ }^{18}$ This preference would have shifted cocoa production away from Ghana, the lowest-cost African producer of cocoa, to the extent that the 5.4 percent margin of preference offset Ghana's lower price. ${ }^{10}$ Ghana, in turn, having lost a sizeable market, might have decided to shift its exports from cocoa to another product. Consumers in the United States might then have had to buy the higherpriced Nigerian cocoa as Ghana and other lower-cost producers phased out production. Even if Ghana continued to produce for the United States market, the price of its product might have increased if it could no longer obtain economies of scale from increased production.

Analysis of trade creation and diversion is complicated by trade effects which occur between different associated states, as opposed to those between associated states and nonmember states. A given EEC preference might shift production away from a prior associate to a more efficient new associate while simultaneously diverting trade from the most efficient nonmember state. Thus, the EEC preference on palm oil had the potential of shifting production away from other African states associated with the EEC under the Yaoundé Convention ${ }^{20}$ and toward Nigeria, a lower-cost producer. ${ }^{21}$ The shift in production might also, however, come at the expense of a nonmember state, such as Indonesia, whose cost of production was even lower than Nigeria's. Along "second best" lines of analysis, the United States would prefer this situation to one in which Nigeria was even less efficient than other associates, as in the case of the EEC preference granted to Nigeria on groundnut oil, where Senegal, the state previously granted a preference, was a lower-cost producer. ${ }^{22}$

17 See G. Patterson, supra note 1, at 351-52.

18 SIX YeAr PLAN, supra note 11, at 125. This assumes that marginal cost equals price and that there are no significant differences in shipping costs or governmental subsidies among exporters.

10 This depends on the assumption that Ghana's price is not substantially lower than Nigeria's, with the result that its goods are cheaper even when it bears the CCT. Nigeria's price in 1965 was $£ 106.5 .0$ and Ghana's was $£ 91.15 .6$. Id. Of course, if the preference is of any value, this is not likely to occur.

20 See note 10 supra.

21 P. OKIGBo, supra note 11 , at 107. The potential for this shift is limited by the ceiling placed on Nigeria's preferences. Id. at 100.

22 See 24 U.N. Food \& Agricultural Organization, Trade Yearboox 420, Table 120 (1970) (compare unit value of palm oil exports for Indonesia and Nigeria). See also P. 
The second effect of interest to the United States, decreases in exports of nonassociated states, occurs when production is shifted away from the United States, whether or not it is the lowest-cost producer. If a preference is granted either by or to the EEC on a good which is produced more efficiently by the preference recipient than by the United States, optimal allocation of resources and the interests of American consumers are furthered even though particular American exporters are disadvantaged. Nonetheless, to the extent that the United States identifies wih the interests of exporters it may still object to the agreement. This problem does not arise, of course, if the United States is the lowest-cost exporter.

To complete the analysis, two refinements must be added. First, the export effect may be incurred on substitute products. Groundnut oil, for example, is a substitute for other oleagenous products such as soybean oil, a major United States export. ${ }^{23}$ The price of Nigerian groundnuts in 1966 was approximately fifty percent higher than that of United States soybeans. ${ }^{24}$ Given a taste preference in Europe for groundnut oil and the lower price of groundnut oil for EEC consumers made possible by the agreement, the rate of substitution of groundnut oil for soybean oil might increase. ${ }^{25}$ This could occur even if, as is presently the case, soybeans enter the EEC duty-free. ${ }^{26}$ Thus, on the basis of

ОблGво, supra note 11, at 110 (compare price of groundnut oil exports for Senegal and Nigeria).

23 The value of United States exports of soybean oil to the EEC in 1969 was $\$ 182,810,594$, while the value of all United States soybean oil exports was $\$ 327,556,365$. See U.S. Bureau of the Census, U.S. Exports of Domestic Merchandise, SIC-Based ProdUCTS AND AREA, 1969, at 86-87, Table 1 (1970).

24 Secretariat of the Contracting Parties of GATT, International Trade 1968, at 130 n,I (1969). In 1968 United States number two soybeans sold for $\$ 110$ per ton while Nigerian shelled groundnuts were $\$ 166$ per ton (CIF European port of entry).

25 For a discussion of substitution theory, see R. LIPSEY \& P. STEINER, EcoNomics 76-78, 104-05, 193-94 (1966); G. Stigler, The Theory of Price 31-33, 38-41 (3d ed. 1966). Evidence of the taste preference for groundnut oil is derived from the fact that, although both soybean and groundnut oil have the same uses, groundnut oil has a significantly higher per capita consumption in the EEC despite its higher price. D. Elz, OILseEd Product NeEds of the European Economic Community 1970, at 105, Table 47, 153, Table A38 (1967).

26 Customs Tariff, supra note 6, Tariff No. 12.01. See also Colonna, The European Economic Community, in 2 Presidential Comm's on International Trade \& Investment Poltax, Working Papers 7, 11 (1971). Even aside from the impact on EEC demand for soybeans, a perhaps more important effect is that on United States export of soybean oil. After the 1960-61 tariff negotiations, since known as the Dillon Round, the EEG-bound duty on soybean oil was 10 percent. 4 U.S. DEP'T OF STATE, GeNeral AGREement on TaRiffs and Trade: ANalysis of United States Negotiations 32, Tariff Item No. $15.07(\mathrm{~B})(\mathrm{II})(\mathrm{c})(2)(\mathrm{aa})$ (Commercial Policy Series No. 197, 1963). This is also the present 
substitution, efficiency and the exporters' interest would lead the United States to oppose the Nigerian agreement. ${ }^{27}$

The second refinement arises from the close relationship between the United States and countries, such as those of Latin America, which may lose exports as a result of association agreements. This decrease in exports may create severe trade imbalances causing unfavorable domestic political repercussions and may occasion offsetting United States expenditures in the form of foreign economic assistance. ${ }^{28}$ Association agreements are likely to affect Latin American exports to the extent that they involve tropical agricultural products. Thus, the Nigerian agreement affected Latin American countries because they are major producers of cocoa and groundnut oil..$^{29}$

Although each association agreement must be judged on its own terms and on a product-by-product basis, ${ }^{30}$ it does not seem unreasonable to begin with the assumption that they both divert trade and decrease exports. Trade diversion is likely because lower-cost producers do not need preferences to compete effectively. This assumption would prove untrue if the lower-cost producer sought an EEC preference to offset the price effect of a prior preference granted to a higher-cost producer. ${ }^{31}$ However, because the EEG is unlikely to impair this prior preference in order to keep its other associates satisfied, ${ }^{32}$ this is not a

EEC rate, no concessions having been made on this item at the Kennedy Round. See Customs TARIFr, supra note 6, at 60 . This could constitute an even higher "effective rate of protection" for the processed product-soybean oil. See G. Curzon, Multilateral ComMercial Diplomacy 229 (1965) (effective rate of protection estimated to be 140 percent). Thus, the tariff preference for Nigeria over the United States would be quite substantial because, under the quota ceiling, its groundnut oil was subject to no tariff.

27 See President Nixon's Report to the Congress, Feb. 21, 1971: U.S. Foreign Policy in the 1970's, 64 DEP'T OF STATE BULL. 401 (1971), in which the President criticized the EEC's preference policy and urged it "to avoid taking any measures which might threaten our sales of soybeans ...."

28 See H. Johnson, Economic Policies Towaro Less Developed Countries 1-43 (1967); Bauer \&: Wood, Foreign Aid: The Soft Option, 59 Banca Naztonale del LAvoro 403-18 (1961). Of course, another way to view the effect on foreign aid expenditures is to say that the United States saves on aid to African countries benefiting from trade preferences. However, an equally plausible view is that there are no savings because aid will be continued in order to balance the political advantages secured by the EEC preference policy.

29 In 1964-65, Latin America-principally Brazil-produced 16.4 percent of the world's cocoa. SIX YeAr PLAN, supra note 11, at 117. In 1965, 80 percent of the reported net export production of groundnuts and groundnut oil come from Nigeria, Senegal, and Argentina. Argentina produced 19.3 percent of this portion. Id. at 74 .

30 This type of analysis is suggested in K. DAM, supra note 16, at 292-95.

31 This was the case for Nigerian palm oil production. P. OkigBo, supra note 11, at 107. This fact accounts, in large part, for Nigeria's desire for association. W. ZARTMAN, supra note 5 , at 81 .

32 See text at note 10 supra. 
strong possibility. Decreases in exports are likely because preferences granted by the EEC are most often on tropical agricultural products produced in volume in Latin America or in substitute form by the United States and because preferences granted to the EEC are usually on manufactured goods likely to be exported by the United States. ${ }^{33}$

\section{B. Expansion of Association Agreements}

The expansion by the EEC of its trade preference system has occurred on a large scale and, as GATT Director General Oliver Long has stated, "could represent a death knell for the multilateral trade system." 34 By early 1971 the EEC had concluded preference agreements with the eighteen African states which were former French colonies; Greece; Turkey; Morocco and Tunisia; Kenya, Tanzania, and Uganda; and Spain and Israel. ${ }^{35}$

In addition to the agreements presently in effect, many other association agreements are in various stages of negotiation. In the Middle East the EEC is negotiating with the United Arab Republic ${ }^{36}$ and Lebanon; ${ }^{37}$ in Africa with Libya, ${ }^{38}$ Algeria, ${ }^{39}$ and the former British Commonwealth states not yet associated (pursuant to British entry into the Common Market); $;^{40}$ and in Europe (besides the United Kingdom,

33 Thus, of the total value of $£ 8.8$ million in world exports for the twenty-six items of reverse preferences given by Nigeria to the EEC, machinery parts accounted for $£ 4.4$ million. P. OKIGBo, supra note 11, at 135-36, Tables 1-2. The United States is a major exporter of machinery parts and in 1970 exported $\$ 378$ million worth. U.S. BUREAU OF THE Census, U.S. EXports, Schedule B Commodity ANd Country, Report FT 410, Dec. 1970, at $1-10$ (1971).

34 U.S. Dep't of Agriculture, Foreign Agriculture, 2 CCH COMM. MKт. REP. I 9349 (1970).

35 The official French texts of these agreements appear at 93 E.E.C. J.O. 1431 (1964) (eighteen African states, Yaoundé I); L 282 E.E.C. J.O. 2 (1970) (Yaoundé II); 26 E.E.C. J.O. 293 (1963) (Greece); 217 E.E.C. J.O. 3687 (1964) (Turkey); L 197 E.E.C. J.O. 3 (1969) (Morocco); L 198 E.E.C. J.O. 3 (1969) (Tunisia). The agreements with Kenya, Tanzania, and Uganda and with Spain and Israel have been called "accords" under articles 111-I4 of the Treaty of Rome because they were limited to a few major products and did not involve other political and social provisions usually contained in association agreements. See Dubois, L'association de la Tunisie et du Maroc à la Communauté, 12 Revue DU MARchÉ Commun 355 (1969). The official French texts of these agreements appear at L 282 E.E.C. J.O. 55 (1970) (Kenya, Tanzania, and Uganda); L 182 E.E.C. J.O. 2 (1970) (Spain); L 183 E.E.C. J.O. 2 (1970) (Israel). For the purposes of this comment, both types of preference agreements will be referred to as association, and the developing countries participating in the agreements will be referred to as associates.

363 Bulc. European Communities, No. 12, at 70 (1970) (first-phase negotiations).

37 Id.

382 CCF COMM. MKr. REP. If 9349 (1970) (preparatory talks).

39 3 Bul. European Communities, No. 7, at 75 (1970) (preparatory talks).

103 Bull. European Communities, Nos. 9-10, at 81 (1970). 
Ireland, Denmark, and Norway for full entry into the Common Market) ${ }^{41}$ with Austria, ${ }^{42}$ Portugal, ${ }^{43}$ Malta, and Cyprus. ${ }^{44}$

The importance of this expansion may be illustrated by its potential effect on the agricultural exports of the United States. The EEC currently imports nearly $\$ 9$ billion in agricultural products. The more than thirty countries which have actual or potential associate status account for at least $\$ 2$ billion of these imports. Of the $\$ 2$ billion, about $\$ 750$ million is represented by products which are competitive with United States agricultural exports. ${ }^{45}$

In response to criticism by the United States and other nonmembers of the system, the EEC has attempted to justify expansion on three principal grounds: (I) the EEC has historical ties to the developing countries; (2) the EEC is using preferences to effect a financial transfer of wealth to the developing countries-i.e., as a form of foreign aid; and (3) by granting preferences to enough exporters of a given commodity, the EEG can establish the basis for a managed price market in a given commodity and thus eliminate the wide price fluctuations which may be harmful to planned export marketing for the lessdeveloped countries. ${ }^{46}$

These justifications, however, seem less than adequate. First, the historical argument may explain association with the former Metro colonies of France or inclusion of the Commonwealth countries if England joins the Common Market, but it obviously cannot account for association with such countries as Israel and Spain, which have had no "special" relationship with the EEC and which are arguably not in the same "developing" category as the states of West or East Africa. ${ }^{47}$

413 Bulz. European Communities, No. 11, at 57 (1970).

423 Bull. European Cominunities, No. 12, at 69 (1970) (negotiations).

434 Bull. European Communities, No. 3, at 67 (1971).

442 CCH COMM. MKT. REP. If 9349 (1970).

45 Id. An argument that this represents an insignificant portion of the United States gross national product only speaks against the significance of foreign trade policy generally. This comment naturally assumes the importance of such policy.

40 See generally Address by M. Edoardo Martino, Member of the EEC Commission, before the Consultative Assembly of the Council of Europe, in 3 Bull. European ComarUNITIEs, No. 4, at 11 (1970); Rochereau, Introduction, 12 Revue du Marché CoMmuN 217 (1969).

47 See the tables of comparative estimated gross national products and other economic indicators in 2 Dep'T of Economic \& Social AfFairs, Statistical OfFice of the U.N., Yearbook of National Accounts Statistics: InTERnational Tables, 1969 (1970). One might argue that Spain and Israel do indeed have a "special" relationship with the EEC - Spain through its general ties with EEC countries and Israel through its particular relationship with West Germany. If this logic is pursued, however, then every country has a "special" relationship with at least one EEC country because of the latter's long existence. 
Second, it is clear that a financial transfer to an associate may in fact be paid for by third parties through decreases in exports. Moreover, an "aid" policy characterized by reverse preferences contains strong counterproductive elements. Thus, for every dollar of "aid" an associated state receives through EEC preferences, it loses a substantial part of a dollar by foregoing the opportunity to buy lower-priced exports. 48

Third, as to the managed market argument, although the EEC is the major market for many African commodities, ${ }^{49}$ such as cocoa, it is not the only market. Conversely, those countries receiving EEG preferences on cocoa are not the only producers. Without almost exclusive control on both the demand and supply sides, the EEC cannot stabilize world prices on a given commodity. Moreover, managed markets may not be desirable on their own merits because they may encourage continued production by nonefficient producers. ${ }^{50}$

More plausible explanations for the EEC expansionist policy are based on (1) EEC foreign economic objectives and (2) the expansionary logic of any large trade preference system.

Relying heavily on American defense, Europe is unable to increase its world influence through other than economic means. ${ }^{.1}$ It is in the economic sphere, in which the EEC is the largest market in the world

48 The claim of the EEC to development goals is belied also by the Common Market's reluctance to grant substantial preferences on semi-manufactured and processed agricultural goods. See U.N. Doc. TD/B/329, TD/B/AC,5/36 (mimeograph). See also Les Préférences: Le Róle qu'elles pouvaient jouer dans le cadre d'une politique d'aide à l'expansion commerciale des pays en voie de dévélopment: un débat nouveau sur des themes anciens, 8 RevUe du Marché CoMmun 371, 375 (1965).

49 In 1969 the EEC accounted for 35.5 percent of the total value of world imports. See 24 U.N. Food \& AGricultural Organization, supra note 22, at 252, Table 64.

50 See L. Towle, International Trade and Commercial Policy 735-36 (2d ed. 1956). The inability of the EEC to manipulate world prices of a commodity derives from the facts that the negotiation of preferences does not include any arrangement to manage the supply of the commodity and that, even if supply management grew out of a preference arrangement, it would be unlikely to succeed because of the lack of control by the participants over world output. The importance of the latter point is confirmed by prior failures of private cartel arrangements. "The restriction of output by cartels has often been neutralized by the simultaneous expansion of output on the part of outsiders. Production or export control cannot be effective unless it covers nearly total world production or exports." Id. See also Hawkins, Epstein, \& Gonzales, Stabilization of Export Receipts and Economic Development-International Commodity Agreements and Compensatory Financing Plans, Bull. of Inst. of Finance, N.Y.U. Grad. Sch. of Bus. Ad., No. 40, at 21-22 (1966).

51 Cf. H. Kissinger, The Troubled Partnership 8-28 (1965). This view may suggest that political objectives, such as the increased prominence of the EEC in shaping the international order, may be independent of the economic objectives of the trade preference policy. Whether this political objective is peculiar to France as compared with the other EEC countries or is traceable to the EEC Commission as a means of maximizing its role is uncertain. Cf. J.W. Evans, The Kennedy Round in American Trade Policy 59-60 (1971). 
for imports, ${ }^{52}$ that European power is at its maximum. The existence of this market allows the EEC to offer significant trade preferences to Europe, Africa, and the Middle East which cannot be offered by the United States or other countries. Also, reverse preferences obviously bring direct gains for EEC export interests by enabling them to compete successfully against lower-cost competitors. Moreover, such reverse preferences are sought to obtain a political commitment by the recipients to the EEC. France has argued that economic benefits should not be granted by the EEC without a political commitment from the country seeking association. ${ }^{53}$

The second explanation for expansion must be found in the expansionary logic of the system itself. Since nonassociated countries face more stiff competition in the EEC market as a result of prior association agreements, they have a major incentive to seek association in order to share in the preference system. The series of agreements on citrus products, first with Tunisia and Morocco and then with Spain and Israel, illustrate the desire of the latter to offset the advantage given to the former. ${ }^{54}$ This expansionary logic is extended by the fact that those seeking to equalize the grant of prior preferences receive new preferences on still other products; the expansion then continues in another sequence of agreements. ${ }^{55}$

The dynamic principles operating on the recipient side find their counterpart on the EEC side. Member countries which, as a result of prior agreements, may be required to forego lower prices for goods when higher-cost producers receive preferences will support new prefer-

52 In 1968 the EEC accounted for 24.6 percent of the total value of world imports and 26.8 percent of world exports. Comparative figures for the United States were 13.1 and 14.3 percent, respectively. See Dep't of Economic \& Social Afrairs, Statistical, Office of the U.N., Yearbook of International Trade Statistics, 1968, at 12-15, Table A (1970).

$53 \mathrm{~W}$. Zartman, supra note 5 , at $82-83$. The actual nature of this political commitment is somewhat unclear. Generally, France has expected support for EEC preference policies. Id. A possible explanation for the specific insistence on reverse preferences is that they entail political costs for the government granting them in that they may increase the cost to consumers of imported goods and that, having "sold" their country on the policy, grantor governments are not likely to withdraw from the preference arrangement without major changes in circumstances.

64 The EEC imports about $\$ 51$ million of citrus products per year. EEC STATISTICAL Office, Aussenhandel Zusammenfassung der EWG-Einfuhr [SUMmary of the EEC IMPORTs] 4, Table 1, CST 51.1-2 (1969). Thus, in 1968, after Morocco, which had world exports of $\$ 83.5$ million, 23 U.N. Food \& Agricultural Organization, Trade Yearbook, 1968, at 156, 159, Tables $39-40$ (1969), and Tunisia, which had world exports of $\$ 3$ million, id. at 156, 160, Tables 39-40, received preferences, Spain, which exported $\$ 111$ million, and Israel, which exported $\$ 88$ million, id. at $154,159,163$, Tables $39-40$, had a great incentive to receive preferences of their own.

$55 C f$. Fudec, GATT or GABB? The Future Design of the General Agreement of Tariffs and Trade, 80 YALE L.J. 1299, 1362-63 (1971). 
ences with comparatively lower cost producers to reduce these prices. It was precisely for this reason that West Germany and the Netherlands supported association with Nigeria-to reduce the costs on goods subject to preferences under the agreement with the eighteen African states. ${ }^{58}$

The logic of expansion is limited, however, by two factors. First, if the EEC is to grant new preferences, it cannot bear too great an expense with respect to goods produced in significant quantity by EEC members themselves. EEC producers would oppose lowering tariffs on goods produced by them because the lower price on foreign goods would cut into their own market. The EEC has met this problem, however, by establishing conditional preferences. ${ }^{57}$ Morocco, for example, receives a preference on citrus fruits only when the EEC's internal production is insufficient to meet demand. When there is a surplus within the EEC, Moroccan citrus becomes subject, as that of other countries, to the "variable levy." 58

Expansion is limited, secondly, by the ability of the EEC to apportion preference benefits among multiple preference recipients. The EEC has attempted to surmount this obstacle through a number of devices. One is the granting of different margins of preference to different recipients. Thus, the EEG was able to negotiate citrus agreements with Spain and Israel and not adversely affect the prior recipients, Morocco and Tunisia, by granting an eighty percent preference to the latter and only a forty percent preference to the former. ${ }^{59}$ Since Spain and Israel were lower-cost producers, ${ }^{60}$ all four countries were given

58 See W. Zartman, supra note 5 , at 33,81 .

57 GATT, BASic INSTRUMeNTs AND SELected Documents 62 (17th Supp. 1970).

58 The system thus works differently depending on whether exporters' prices are lower or higher than the established "reference price." See Dam, The European Common Market in Agriculture, 67 Colum. L. REv. 209, 256-65 (1967). When Moroccan prices are lower than the reference price-which implies that the EEC is oversupplied internally with citrus-Morocco gets no preference and is subject to the variable levy. When Moroccan prices are higher than the reference price, on the other hand, a preference is granted. This is accomplished by the fact that an eight to fifteen percent tariff (depending on the particular citrus fruit) is customarily levied on imports whose prices (CIF European port of entry) are higher than the reference price. See Dubois, Le Régime des éschanges dans le cadre de l'accord créant une association entre la communauté économique europeenne et Le royaume de Maroc, 14 Revue du MarchÉ Commun 41, 50-51 (1971).

59 Dubois, supra note 58. Turkey, as part of its association agreement, also receives a forty percent conditional preference on citrus.

60 That Spain and Israel are lower-cost producers of citrus fruits than Morocco and Tunisia is strongly suggested by the comparative values of their citrus exports per metric ton. In 1969 these were as follows: Spain, \$105; Israel, \$130; Morocco, \$139; and Tunisia, \$146. See 24 U.N. Food \& Agricultural Organization, supra note 22, at 159-70, Tables $40-42$. 
comparable advantages in the EEG market. A second principal device is quantitative restrictions. The EEC, by selecting appropriate ceilings for tariff quotas, can divide its market demand among a number of preference recipients. ${ }^{61}$

\section{United States Response to Trade Preferences}

The four principal responses of the United States to the development of the EEC trade preference system have been (1) challenges under the GATT; (2) acceptance of the "general preference" alternative, whereby all developed countries jointly grant preferences to all lessdeveloped countries; (3) negotiation of its own preferences, principally with Latin America; and (4) imposition of the ten percent surcharge.

1. Challenges Under the GATT. Although any definition of the GATT is difficult, ${ }^{62}$ for the purpose of this comment it may be considered to be the substantive and procedural rules embodied in the legal document bearing the name General Agreement on Tariffs and Trade. ${ }^{63}$ This agreement is adhered to by the United States and the other major nations of the world. ${ }^{64}$

The central substantive rule of international trade that GATT establishes is the "most-favored nation" principle. It provides that

any advantage, favour or privilege or immunity granted by any contracting party to any product originating in or destined for any other country shall be accorded immediately and unconditionally to the like product originating in or destined for the territories of all other contracting parties. ${ }^{65}$

One of the major exceptions to this principle is the establishment of a free trade area. ${ }^{66}$ In order for a trade agreement to qualify as a free trade area, it must satisfy two main requirements: (1) "substantially all" the duties and restrictive regulations of commerce must be eliminated in the trade of the participants, ${ }^{67}$ and (2) a "plan and a schedule"

61 This was the device used in the Nigerian Agreement. See text at note 12 supra.

62 K. DAM, supra note 16, at 335 \& n.l; Hudec, supra note 55, at 1299 \& n.2.

63 See note 3 supra.

61 In May, 1970, there were seventy-seven contracting parties to the GATT. GATT, supra note 57 , at vii.

65 GATT art. I, para. 1.

66 Id. art. XXIV; see K. DAM, supra note 16, at 274-95; J. JACKson, WORLD TrADE AND THE LAW of GATT 575-623 (1969). The theory behind the exception was that customs unions, as opposed to preference arrangements, would eliminate all customs barriers between participants and thus, on balance, support the objectives of free trade policy. See C. WilcoX, A Charter for World Trade 70-71 (1949).

67 GATT art. XXIV, para. 8(a)(1). 
must be established for the complete elimination of all restrictions on trade. ${ }^{68}$

The "substantially all" requirement is subject to a great deal of ambiguity. Thus, it is possible that the requirement may demand a reduction on all items of trade or only on items covered by a particular trade agreement. ${ }^{69}$ Moreover, the requirement may or may not be inconsistent with the use of tariff quotas, which set ceilings on tariff reduction. ${ }^{70}$ In spite of this ambiguity, it is clear that most if not all EEC agreements do not meet the requirements for a free trade area. For example, in the 1964 and 1970 Yaoundé agreements with the eighteen African states, there was no apparent "plan" or "schedule " to eliminate internal barriers to trade; quantitative restrictions were broadly applied to African exports, raising the "substantially all" question; and, in the case of the 1964 agreement, some of the associated states' tariff levels were to be raised. ${ }^{71}$

The United States has attempted to limit the expansion of the EEC preference system by challenging these agreements under the GATT as inconsistent with the substantive requirements of a free trade area. Such challenges are facilitated by the GATT provision that any contracting party deciding to enter into a free trade area arrangement must promptly notify the other contracting parties and provide information

88 Id. art. XXIV, para. $5(\mathrm{c})$. One additional requirement of less direct concern is that the common external tariffs of the free trade area participants not be higher or more restrictive than those existing previously. Id. art. XXIV, para. 5(b). Pressures to increase tariffs may occur if the external tariffs of participants are not high enough to make a preference meaningful-i.e., if the lowest-cost producer can outsell the free trade participant even when subject to the tariff.

69 From the viewpoint of economic efficiency, the "substantially all" requirement should be interpreted to mean a sizeable reduction on all items of trade. See K. DAM, supra note 16, at 279-80; GATT, BAsIC INSTRUMents AND SElected Documents 99 (6th Supp. 1958).

$70 \mathrm{~K}$. DAM, supra note 16 , at $280-81$. The GATT provides that quantitative restrictions, as "restrictive regulations of commerce," must be eliminated on "substantially all" intermember trade, except that, "where necessary," quantitative restrictions may be imposed if permitted under article XI (protection of certain agricultural and fisheries products), article XII (safeguard of balance of payments), article XV (exchange restrictions approved by International Monetary Fund), and article XX (specific exceptions such as "necessary to protect public morals"). GATT art. XXIV, para. 8. Moreover, subject to certain exceptions, it requires that quantitative restrictions be applied in a nondiscrim. inatory fashion. Id. art. XIII. The serious problem arises when the EEC uses the tarift quota device to apportion preferences among recipients. See text at note 57 supra. Since the use of this device is central to the apportionment and thus to the entire EEC preference system, it is in the interest of the United States to attack its use within trade preference agreements, as it did in the case of Yaounde I. See GATT, BASIC INSTRUMENTS AND SELECTED Documents 100, 103-04, 113-14 (14th Supp. 1966).

71 GATT, supra note 70, at 100-15. 
about the association to assist review by member nations. ${ }^{22}$ It is during the review process that the United States may raise its objections.

GATT review has, however, proved inadequate to protect United States interests because of the availability under the agreement of two broad waiver provisions which permit the contracting parties to waive conformity with the substantive requirements of free trade areas. The first provision permits a two-thirds majority of the contracting parties to approve the agreement if "such proposals lead to the formation of ... a free trade area in the sense of this Article."73 This waiver presupposes a thorough GATT review of the agreement and a finding that there is reason to believe the arrangement will lead to a free trade area. A second, even more general provision requires no specific findings and therefore operates as a general escape clause. This waiver requires a two-thirds majority of all parties voting, which must comprise more than half of the entire GATT membership. ${ }^{74}$

In only one case, the initial GATT review of the Spain and Israel agreement in 1969, has United States opposition to EEC trade preference agreements enjoyed even limited success. There, GATT's Working Party rejected application of escape clause treatment and in so doing seemed to lay down certain limits on the granting of waivers. ${ }^{75}$ Its report urged that preferences be restricted to less-developed countries on a nondiscriminatory basis to avoid violations of the most-favored nation principle. ${ }^{76}$ This policy would, however, not be consistent with that principle-it would only generalize the exception to it, thus minimizing "bilateralism" in the field of tariffs.

Following the GATT rejection, the ECC indicated that it would be willing to review the agreement provisions. This decision of the EEC cannot, however, be taken as a clear sign of the effectiveness of GATT challenges by the United States. An equally plausible explanation of this deference to GATT could be the EEC's own problems in negotiating agreements between the African and Mediterranean preference recipients on the division of benefits. ${ }^{77}$ This view is supported by the fact that the most recent Spain-Israel agreement makes few changes along lines recommended by GATT. ${ }^{78}$

\footnotetext{
72 GATT art. XXIV, para. 7(a).

73 Id. art. XXIV, para. 10.

74 Id. art. XXV, para. 5.

76 GATT, supra note 51, at 61-69 (1970).

76 Id. at 67.

77 See Dubois, supra note 58 , at 50-51.

78 See GATT, supra note 51, at 61-69.
} 
GATT treatment of the Yaoundé agreements of 1964 and 1970 demonstrates the more usual result-a willingness to support waiver despite nonconformity with substantive requirements. Thus, review of the first agreement was never concluded and resulted only in a recommendation for further study, ${ }^{79}$ which was in effect a waiver of rejection of the agreement. Moreover, in 1970 the Working Party recommended approval of the second agreement under the more specific waiver, finding that the agreement was moving toward freer trade between the participants. That recommendation was sustained by the GATT membership despite intense opposition from the United States, Japan, Chile, and Argentina. ${ }^{80}$

The complete futility of GATT review has been indicated by the EEC's refusal, in the case of GATT rejection of a specific waiver for the Morocco-Tunisia agreement, ${ }^{81}$ to be bound by the GATT finding. After rejection, the EEG stated unilaterally that it deemed the procedure for the examination of the agreements completed and took the position that the application of the specific waiver was automatic and required no vote by the contracting parties. ${ }^{82}$ The EEC was stating in effect that if it felt waiver was justified, it would consider waiver granted even in the face of express GATT rejection.

The ease of obtaining waivers and the EEC's refusal to be bound by GATT decisions represents the failure of the legal argumentation policy pursued by the United States in the GATT forum. It is clear that the EEC will continue to expand its trade preference system despite GATT disapproval. Whereas the United States continually stresses that these agreements must meet or have the potential to meet substantive GATT requirements, the EEC dismisses this approach and finds sufficient justification from its own proclaimed reasons for seeking association. Its attitude is clearly reflected in its 1970 annual report:

In all these cases, ... there is a lack of proportion between the United States' attitude and requests, and the actual economic or commercial significance of this question. The American attitude appears to the Commission even less comprehensible in view of the political importance of the special relations which the Community

79 See GATT, supra note 70 , at $100,115$.

80 Le Monde Diplomatique, Jan., 1971, at 23, col. 1.

81 See 3 Bulz. European Communities, No. 11, at 66 (1970). As the Working Party noted, "[T] he preferences had been put in force on 1 September without waiting for the outcome of the examination by GATT of the application for a waiver. They pointed out that such an early introduction of preferences created a de facto situation which was without precedent." Id. at 68.

823 Buzl. European Communitres, Nos. 9-10, at 17 (1970). 
maintains in order to take account of obvious historical, geographical and economic factors. ${ }^{83}$

The ultimate source of the GATT failure may be found in the reluctance of the United States to engage in "controlled" retaliation to EEC action by withdrawing tariff concessions granted to the EEC, a withdrawal which is authorized after approval by GATT.84 While United States policy did assume a new tack after the failure of GATT, it was not toward retaliation but competition with the EEG based on a new United States acceptance of preferences. This departure from commitment to the most-favored nation principle signaled a major shift in United States foreign economic policy.

2. Acceptance of the "General Preference" Alternative-a. The proposal. The history of the interaction of the United States and the EEC on the issue of general preferences reveals three significant themes: the reluctance of the EEC to grant general preferences at the expense of associates, the refusal of the United States to grant general preferences to associates and the consequent inducement for associates to abandon their EEC commitments, and the failure of the United States competition strategy.

General preferences, as advocated by the less-developed countries since the early 1960s, are preferences extended by developed countries to all less-developed countries on all export items of interest to the latter. Such preferences would consist of lower tariff rates for imports from the less-developed countries into the developed countries than are set for trade between the developed countries. ${ }^{85}$ A major advantage that the United States perceived in such a system was the effective end to the expansion of EEC association. ${ }^{86}$ General preferences had the potential of "internationalizing" the granting of preferences, thus terminating the EEC's domination of the field. Moreover, since the lessdeveloped countries' proposal did not envision reverse preferences, it had the potential of offering a viable alternative to affiliation with the EEC system.

83 Comm'n of the European Communitizs, Fourth Genersi Report 323 (1970).

84 GATT art. XXIII. It provides:

1. If any contracting party should consider that any benefit accruing to it directly under this Agreement is being .... impaired or that the attainment of any objective of the Agreement is being impeded as the result of ...

(c) the existence of any other situation, ... [and]

2. ... If the Contracting parties consider that the circumstances are serious enough to justify such action, they may authorize a contracting party or parties to suspend ... concessions."

See K. DAM, supra note 16 , at $353-68$.

85 See generally G. PATtERson, supra note 1, at 323-47.

88 See text at nove 106 infra. 
Since 1964 the United Nations Conference on Trade and Development (UNCTAD), whose membership is composed of the seventy-seven less-developed countries, ${ }^{87}$ has served as a forum for the general preference proposal. The concept was originally opposed by both the EEC and the United States, although for different reasons.

b. Initial opposition. In 1963, preliminary to the first meeting of the underdeveloped countries at the 1964 World Trade and Development Conference, the EEG and the United States voiced opposition to one of the less-developed countries' first proposals, which would have eliminated all tariffs on products of special interest to those countries, principally tropical foods and selected manufactured and processed goods. The EEG refused to endorse the proposal because the dismantling of trade barriers would render meaningless the margins of preference it had granted to the Yaoundé states and would expose EEC producers to significant competition.88

Instead, the EEG proposed a "managed market" concept, to be directed to the organization of international trade in products of interest to the less-developed countries. The EEC felt that such organization was essential to protect the interests of the associates. ${ }^{89}$ When the managed market proposal met with general disapproval, the EEC formulated another alternative, the Brasseur Plan, a system of selected and negotiated preferences as opposed to the general and automatic preferences being advocated by the less-developed countries. ${ }^{90}$ Although the plan had some advantages with respect to trade diversion since it would allow an examination of the economic consequences of subjecting any particular product to a preference, its main advantage was protection for the associates by the granting of a preference of somewhat less value than association preferences on the same product and by the selection for preferences of products other than those already covered in association agreements. ${ }^{91}$

The United States during this period opposed any form of prefer-

87 See E. PARsons, A REVIEW OF UNCTAD II (1968). For background on the formation of UNCTAD, see $K$. Hagras, United Nations Conference on Trade and Development 77-109 (1965).

88 G. PATterson, supra note 1 , at 349 n.46. As the author notes, involved in the EEC refusal "was that for them any such dismantling of trade barriers would deprive some of the associated states of their privileged position in the Six and could also, via its effects on free trade arrangements among themselves and so on the products in question, change the internal balance of the quid pro quo within the Six." Id.

89 See GATT, supra note 51, at 63 (managed market argument used to support citrus preferences).

906 UNCTAD, ProceEdings 23-25 (1964).

91 See generally U.N. Doc. TD/B/AC.1/1, at 21 (1965) (official statement of UNCTAD Sec. Gen. Raúl Prebisch outlining objections to the Brasseur Plan). 
ences. Aside from its steady commitment to the most-favored nation principle, American policy makers feared that discussion of the question of general preferences during the Kennedy Round would reduce incentives for lowering tariff barriers on a nondiscriminatory basis. ${ }^{22}$ Officials were also concerned that congressional approval could not be obtained for such preferences since a further lowering of tariffs would decrease the margin of protection for American producers on items of "special interest" to the less-developed countries. ${ }^{03}$ The final ground for United States opposition was that such preferences were likely to divert trade. ${ }^{94}$

The World Trade Conference of 1964 was unwilling to accept the Brasseur Plan and instead called for preferences to be "extended uniformly by all developed countries in a nondiscriminatory manner."95 However, the African associated states, unwilling to give up their exclusive EEC preferences, successfully inserted a section providing that "special treatment may be granted by developed countries to the less developed among developing countries," 96 a provision which would permit a specific exemption without necessarily generalizing exemptions for future association agreements. Differences among the parties to the Conference resulted in no plan being adopted. Moreover, as the EEC expanded its association agreements to include more developed countries, such as Spain and Israel, the strategy of the "lessdeveloped" exemption became insufficient to protect its associates' interests.

c. United States acceptance. Between 1964 and 1968, the year in which the second World Trade Conference (UNCTAD II) was held, three major interrelated events occurred: the EEC expanded its association agreements, the United States changed its policy on general preferences, and the less-developed countries not associated with the EEC campaigned even more strongly than before for general preferences.

The nature of the EEC association expansion has already been examined. ${ }^{97}$ The interplay between this expansion and general preferences is, however, of interest. Expansion not only tended to undermine whatever unity may have existed among the less-developed countries in their demand for general preferences but also fed itself on the failure

92 G. PAtTERson, supra note 1, at 354. See also H. Johnson, supra note 28, at 35-36.

03 G. Patterson, supra note 1 , at 355 .

94 H. JoHNson, supra note 28, at 36. For a summary of arguments for and against general preferences, see McNeill, Tariff Preferences for Developing Countries, 60 AM. Soc. Int'l Procendings 93 (1966). See also J. Pincus, Trade Aid and Development 197-219 (1968).

95 U.N. Doc. E/Conf./46/AC.2/L40, at para. VII (1964).

80 Id.

97 Text at note 35 supra. 
to implement such a system. Association instead of general preferences appealed to certain less-developed countries which were not interested in indefinitely deferring participation in a preference system. ${ }^{88}$

The success of EEC expansion also was responsible for the first major change in United States policy on preferences. Thus, in late 1967 President Johnson indicated that the United States would now be willing to "explore" a scheme by which all developed countries would grant tariff preferences to all less-developed countries.99 This proposal singled out certain products, principally semi-processed as opposed to raw ones, ${ }^{100}$ which were not generally covered under association agreements - because inclusion would threaten internal EEC processors of raw products. The proposal was, therefore, attractive to both associates and nonassociates.

A major contributing factor to the decision to change policy seems to have been pressure brought by Latin America. As one United States policy maker stated:

Latin American countries have viewed the EEC-African Association system with fear and suspicion. Since Africa and Latin America produce many of the same products, the EEG's grant to African countries of preferential entry into the EEC has put Latin America, which faces the substantial common-external tariff, at a considerable disadvantage in the markets of the Community. ${ }^{101}$

Another probable contributing factor was the failure of the Kennedy Round to lower tariffs or eliminate nontariff barriers on items of interest to the less-developed countries, especially processed agricultural produce and semi-manufactured goods. ${ }^{102}$ This failure was, of course, due partly to the EEC's unwillingness to narrow the margins of preferences available for old and new associates. ${ }^{103}$

98 G. PATterson, supra note 1 , at 368 . The refusal to wait was partially responsible for Nigeria seeking association.

89 This decision was announced at the April 13, 1967 meeting of the chiefs of state of the countries in the Organization of American States, 56 DEP'T STATE Bunc. 706, 709 (1967).

100 The Johnson proposal was subsequently elaborated upon in a meeting of the Ministerial Council of the Organization for Economic Cooperation and Development. See Peterson, The United States and the Developing Countries, 2 ForeIGN TRADE REv. 393, 401 (1967); cf. 57 DeP'T STATE BuLL. 876 (1967) (communique issued by the Ministerial Council on November 30, 1967).

101 Peterson, supra note 100 , at 401.

102 UNCTAD, THE KENNEDY Round's EstTMATED EFFEcts on TARIFF BARRIERs, pts. 1-2, at 17-18 (1968) (report of Secretary General Prebisch). Whereas the overall tariff cuts at the Kennedy Round were thirty-six percent, on items of interest to the developing countries the cut was only twenty percent.

103 This was the view of Agency for International Development Director Sidney Wein- 
-Despite the change in United States policy, little real progress was made at the 1968 Conference because the United States and the EEG countries, particularly France, could not agree on the principles of any plan. ${ }^{104}$ Two major issues still divided them: the selection of products and the disposition of the EEC association agreements.

d. Inability to formulate a "common" plan. Following UNCTAD II, the developed countries agreed to undertake the formulation of a "common" general preference plan for presentation to UNCTAD in 1970. Such a plan was envisioned as a joint offer, on unified principles, of general preferences by all developed countries to all less-developed countries. The Organization for Economic Cooperation and Development (OECD) was to serve as the forum for arriving at a common plan which would attempt to resolve conflicts among the developed countries with respect to the products and policy of a general preference plan. Not unexpectedy, the developed countries could not agree and instead submitted separate proposals to the Special Committee on Preferences, the working group of UNCTAD. ${ }^{105}$ Attention will be focused on the two most important of these plans, those of the United States and the EEC.

i. Initial United States plan. The initial United States plan contained eight major points: (1) preferential duties would be set at zero; (2) preferences would be granted on manufactured and semi-manufactured goods-except for textiles, shoes, and petroleum productsand on a selected list of agricultural and fishery products; (3) no ceilings would be established for the import preferences, but a standard escape clause would protect domestic industry; (4) the preferences would last no more than ten years and would neither "constitute a binding commitment" nor "impede future tariff reductions on a most-favored nation basis"; (5) a common plan would be adopted by all major developed countries; (6) United States preferences would not be granted to those countries already granted special preferences by developed countries; (7) the United States would not grant preferences to countries granting reverse preferences; and (8) the preferences actually

traub. He observed: "One major reason ... that tariffs and other trade restrictions have been and are being maintained [is] for the purpose of permitting preferences. This is certainly the reason for the EEC tariffs on coffee, cocoa, bananas, and other tropical products-the tariff permits preferences to Associated African producers." S. WenNTraUb, TRAdE Prefrerences for I.ess Developed Countries: AN ANalysts of U.S. Poltcy 131 (1966).

104 Cf. Note, La Conférence de New Delhi, 14 Annuarre Français de Drolr InternaTIONAL 582, 592 (1968).

105 U.N. Doc. TD/B/243/Rev.1 (mimeograph). Mimeographed . United Nations materials cited in this comment are not dated but appear to have been issued within the past year. 
granted would be to all less-developed countries, no distinction being made between less- and least-developed countries. ${ }^{100}$

ii. Initial EEC plan. The initial EEC plan was quite different from that of the United States. ${ }^{107}$ As submitted to the OECD, it contained the following provisions: Preferences would be equivalent to zero duty, as under the United States plan, but would apply only to manufactured and semi-manufactured products and not to agricultural products and would be granted only within a fixed ceiling. The ceiling would be established on a product-by-product basis and would generally be equal to past EEC imports of the particular product plus five percent of the value of all other imports of the same item from all other countries: It was further provided that, "in order to limit the preferences granted to the more competitive developing country or countries and to reserve a substantial share for the less competitive, preferential imports of a given product from a single developing country should not, as a general rule, exceed 50 [percent] of the ceiling fixed for that product."108

The proposal was a quite sophisticated attempt to protect the EEC's position with the associates. It covered no raw agricultural products, the main subject of past EEC preferences. Moreover, linking the ceiling to past performance data froze in the past advantages of the preference takers. Finally, the fifty percent ceiling for any one country was added insurance that the least-efficient producers, usually the associated African states, would still be advantaged. Many of these limitations were demanded by countries with whom the EEG was currently negotiating for association. ${ }^{109}$

Before transmitting a plan to the Special Committee, the United States made major revisions in its plan, while the EEC made very few. These changes were designed to maximize acceptance by the lessdeveloped countries. These were the plans considered by the seventyseven country group.

iii. Revised plans. The revised plan of the United States embodied a modification of its position on the granting of preferences to the associated states. It still excluded from its coverage those countries granting reverse preferences to the EEC. However, this exclusion would be eliminated if the recipients provided adequate assurance that the preferences would be phased out within a reasonable amount of time

106 U.N. Doc. TD/B/AC.5/24/Add.5 (mimeograph). Due to the EEC commitment to its associates, there seems to have been little basis for the United States to have believed that the EEC would accept the plan.

107 See 3 Bul.. European Communities, No. 1, at 78, 79 (1970).

108 U.N. Doc. TD/B/AC.5/34/Add.5 (mimeograph).

109 See 14 E.E.C. J.O., No. C 13, at 9 (1971). 
and in any event by 1975. The United States also abandoned its demand for a common plan. Instead, its "submission emphasize[d] the importance of adopting schemes that are harmonized to the extent possible and can be expected to achieve comparable results, thus ensuring equitable burden-sharing." 110

The abandoning of the common plan only represented an acknowledgement of the inability to achieve agreement. The equitable burdensharing concept seems to indicate that the United States viewed as burdensome the granting of preferences which could produce higher costs to American consumers and increase competition to American producers. Of course, to the EEC, which had designed its association agreements to minimize costs to domestic producers, higher costs to its consumers was the price of achieving its foreign economic objectives. The United States, on the other hand, did not at this time consider the preference system politically advantageous.

The change of position on coverage for associated states was an attempt to present some difficult choices to these countries. If they were presently to give up their EEG preferences and phase out their reverse preferences, they would have had increased access to the United States market. It was unlikely, however, that this type of competitive inducement would work. Benefits of the EEG preference system were actual, whereas the United States system was contingent on, among other factors, congressional approval. ${ }^{111}$ Moreover, for most associated countries and those negotiating for association, the EEC represented a larger market for their exports than the United States. ${ }^{112}$ Furthermore, entry into the United States preference system would occasion competition with the Latin American countries that they could avoid in the EEC

110 U.N. Doc. TD/B/AC.5/34/Add.5 (mimeograph). In October, 1970 the United States made still one further change in its proposal, dropping its objection to special preferences -those given by the EEC to associates-but retaining the requirement for a phase-out of reverse preferences. Although the United States indicated that it would be "reasonable as to the kind of assurance" it would accept for the phase-out, any kind of commitment by developing countries would upset their association relationships. The change in the United States position seems to reflect the failure of using participation in its own plan as an incentive for altering association relationships. Moreover, its new position allowed it to pursue its own special preference policies. U.N. Doc. TD/B/AC.5/34/Add.5/Rev.1/ Corr.1 (mimeograph).

111 Since under section 251 of the Trade Expansion Act of 1962, 19 U.S.C. $\$ 1881$ (1970), reductions in tarifts must be on a most-favored nation basis, the President would have to go to Congress for new legislation to implement the proposal. The contingency problem could not have been side-stepped by countries making their own contingent commitment to the United States plan pending congressional action because such a strategy would have required making a break with the EEC which could incur political costs, even if the actual break was only contingent.

112 Cf. note 52 supra. 
system. Finally, a certain degree of political commitment to the EEC had accompanied their entry into the association.

The revised EEC plan contained no shift in principles. The major change was, rather, an agreement to grant non-tariff quota preferences on processed agricultural items by reducing the CCT by a fixed percentage. ${ }^{113}$ The EEG could, of course, set the margin of preference at a high enough rate to protect the margin granted to associated states. It was in effect proposing a triple tariff plan. ${ }^{114}$

iv. The "agreed conclusions" of UNCTAD. The Special Committee on Preferences, faced with the disparate plans, ${ }^{115}$ could not resolve the differences. As a result, it issued a peculiar report, entitled "Agreed Conclusions of the Special Committee on Preferences," which did little more than record the areas of agreement and disagreement among the various plans. ${ }^{116}$

While this report characterized the preferences to be granted as "generalized, non-reciprocal and non-discriminatory" and granted for the purpose of increasing the export earnings and rates of development of the less-developed countries, it was clear by the end of the Conference that the preferences proposed were only nonreciprocal; they were neither general nor nondiscriminatory. This was because associated countries were unlikely to end association and thus would be unable to participate in the United States preference plan. ${ }^{117}$

Consequently, the EEC and the United States actually drew up lists of products and beneficiaries which would receive special preferences. While the United States excluded the associates, the EEC made certain through its manipulation of product coverage, exception lists, depths of tariff cuts, and ceilings that the new beneficiaries would not prejudice the position of the associates. In effect, the EEC aimed its benefits at

113 U.N. Doc. TD/B/AC.5/34/Add.1 (mimeograph).

114 The multiple tariff level device had been proposed originally in the context of association negotiations with Nigeria in order to protect old entrants against potential new ones. W. ZARTMAN, supra note 5, at 84 . Now it was to be used to protect all associates against the potential general preference takers.

118 The plans were submitted to UNCTAD on September 19, 1970. U.N. Doc. TD/B/ AC.5/34 (mimeograph).

116 The "agreed conclusions" appear in U.N. Doc. TD/B/AG.5/36 (mimeograph).

117 Jamaica, for example, pointed out that this provision excluded Commonwealth countries as well as associates, although by the end of 1970 its apprehension was probably related more to its hope that it would receive preferences from the EEC upon entry of the United Kingdom into the Common Market. Cf. Lemaitre, Négociations Anglaises: Les Six se familiarisent avec le dossier mais n'arrétent pas de veritables tactiques communes, REvUE DU MARCHE COMMUN 127 (1970). It asked the rhetorical question "whether it was reasonable to expect a developing country ... to risk its political, economic and social stability in order to obtain possible advantages whose value might yet prove to be negligible." U.N. Doc. TD/B/AC.5/36/Add.4 (mimeograph). 
Africa, Europe, and the Middle East, while the United States held out benefits for Latin America-all under the guise of a general preference plan. As Bulgaria perceptively noted:

We come across such forms of words as system of generalized preferences, generalized preferences, generalized system of preferences and generalized preferences. We do not insist on any textual changes now, but understand that all formulations used have in mind the individual submissions. ${ }^{118}$

v. Implementation. The EEG plan went into effect unilaterally on July 1,1971 and was to remain in effect for only one-half year on an experimental basis. ${ }^{119}$ One major feature, not included in its UNGTAD II proposal, was added-the burden of accepting goods with given margins of preference under a ceiling arrangement was to be shared on a percentage basis among the individual EEC states. ${ }^{120}$ Since the United States has not adopted the plan, but instead raised tariffs generally under the ten percent import surcharge, the EEC still dominates the preference field. By adding UNCTAD II preferences to those of the association, if only on a trial basis, the EEC has expanded its system. to all of the less-developed countries, including Latin America.

Latin American countries, which had expected to benefit in major fashion from the United States preference system, instead faced the import surcharge for more than four months. Although their benefits under the EEG plan are limited by the freeze-in provisions of the ceilings and by the priorities given to associates, they ironically are receiving more special trade benefits from the EEC than from the United States.

The United States response to general preferences involved a competition strategy-an attempt to weaken the EEC trade preference system by bidding for the affiliation of old or potential associates to join its own preference system by offering lower tariffs. The success of this strategy depended on offering inducements on a comparatively

118 U.N. Doc. TD/B/AC.5/36, Annex II (mimeograph) (emphasis added). Some countries were caught in the crossfire. Nigeria, for example, would not have received preferences from the EEG or the United States on cocoa powder, paste, butter, groundnut oil, palm oil, veneer sheet, plywood, or petroleum products. U.N. Doc. TD/B/AC.5/36/Add.5, Annex I (mimeograph). These products were evidently excluded from the EEC list because of the demands of the eighteen African states and from the United States list because the products were the subject of EEC special preferences.

119 The plan as adopted by the EEC appears at L 142 E.E.C. J.O. 1 (1971). See also L 146 E.E.C. J.O. I-43 (1971); C 63 E.E.C. J.O. 1 (1971). GATT has approved a general waiver under article XXV of the Agreement for the general preference plan. GATT, Press Release No. 1082, June 26, 1971.

120 L 142 E.E.C. J.O. 2 (1971). 
favorable basis, but this was not possible given the attractiveness of the EEC market and the speculative nature of benefits contingent on congressional approval. Perhaps realizing that the competitive strategy would fail, the United States turned to other policy alternatives.

3. Preferences for Latin America. Even if the United States could not hope to attract preference recipients away from the EEC, the alternative was open to establish its own trade preference system limited principally to Latin America, a possibility which was raised by the United States at the close of the UNCTAD II meeting. ${ }^{121}$ When the EEC announced its July 1, 1971 target date for the implementation of its general preference plan, ${ }^{122}$ the United States apparently felt compelled to proceed with its own plan tailored to the needs of Latin America. Thus, in an April, 1971 speech before the Geneva Assembly of the Organization of American States, Sec. of State William P. Rogers stated that congressional authorization would be sought for preferences on five hundred products requested by Latin American countries. ${ }^{123}$ With the imposition of the surcharge, however, all plans to introduce the enabling legislation ceased. From the point of view of the United States, a preference system with Latin America would have been at best a holding action which could not lead to the elimination of the EEC preference system. The United States turned instead to a strategy of retaliation designed to affect the EEC where the United States had more leverage-in the market it provided for EEC exports.

\section{Imposition of the Surcharge: The Strategy of Retaliation}

On August 15, 1971 President Nixon proclaimed a ten percent surcharge on all imports, subject to certain exemptions. ${ }^{124}$ Its general

121 The United States stated that, "if special preferences were maintained by other countries, the United States reserved the right to exend comparable special preferences." U.N. Doc. TD/B/AC.5/36/Add.4 (mimeograph).

1222 CCH Comm. MKr. REp. If 9425 (1971) (press release of the EEG Commission, issued March 18, 1971).

123 The Secretary said:

The United States Government has decided, in large part because of the consulta. tions within this organization, to include in our own preference system some 500 products requested by Latin American countries. The total value of U.S. imports of these items from Latin America in 1969 was $\$ 650$ million.

Action on generalized preferences will require congressional approval. The President has asked me immediately on my return from this meeting to initiate consultations with Members of Congress with a view to early introduction of legislation to grant to developing countries generalized tariff preferences on a wide range of products, including the 500 items requested by Latin America. The Administration will make a concerted effort to secure enactment of this legislation.

64 Dep't State Bulc. 602, 604 (1971).

124 Pres. Proclamation No. 4074, 36 Fed. Reg. 15,724 (1971). Citations to particular language in the Proclamation are for convenience made to parts and subparts or to paragraphs. 
purpose, as originally formulated by Treasury Sec. John B. Connally, was to "guarantee" the revaluation of major undervalued foreign currencies and thus to rectify the United States balance-of-payments deficit. ${ }^{125}$ Three conditions were set for removal of the surcharge: revaluation of currencies, liberalization of specific barriers to trade by Japan and the EEC, and increased defense burden sharing by United States allies. ${ }^{126}$

On December 20, after the surcharge had been in effect more than four months, it was removed. ${ }^{12 \tau}$ The removal accompanied a substantial currency realignment, partially attributable to a commitment by the United States to devalue the dollar by 8.57 percent, ${ }^{128}$ and followed a West German pledge to increase its contribution to NATO arms expenditures by $\$ 1$ billion. ${ }^{129}$ Conspicuously lacking in the settlement were any trade concessions by either the EEC or Japan.

Consideration of the surcharge will proceed in two steps: (1) an analysis of the relationship between the surcharge and trade preferences and (2) an examination of the purported legal authority for the surcharge.

\section{A. Effects on Trade Preferences and Policy Alternatives}

1. Relation to Trade Preferences. The removal of trade preferences was one of the major trade concessions that the United States attempted to secure before removing the surcharge. The question of preferences was raised in three forums: at the GATT, in the Group of Ten, and in trade negotiations between the President's Special Representative for Trade Negotiations and the EEC Commission.

In mid-November, 1971, following the imposition of the surcharge, the United States began its assault on preferences within the GATT by

125 N.Y. Times, Aug. 18, 1971, at 1, col. 6 (city ed.); N.Y. Times, Oct. 1, 1971, at 1, col. 8 (city ed.) (statement of Secretary Connally before the Board of Governors of the International Monetary Fund). See generally Hearings on International Aspects of the President's New Economic Policies Before the Subcomm. on International Trade of the Senate Comm. on Finance, 92d Cong., 1st Sess. 101-32 (1971) (testimony of Secretary Connally) [hereinafter cited as NEP Hearings].

126 See authorities cited note 125 supra. See also N.Y. Times, Sept. 4, 1971, at 8, col. 1 (city ed.) (statement of Asst. Treasury Sec. Paul A. Volcker before a meeting of the Group of Ten finance ministers); Wall Street Journal, Dec. 2, 1971, at 3 col. 1 (Midwest ed.) (report on the Group of Ten meeting).

127 President Nixon announced the removal while meeting with Prime Minister Health of Britain in Bermuda. N.Y. Times, Dec. 21, 1971, at 1, col. 4 (city ed.). The removal of the surcharge was effected by Pres. Proclamation No. 4098, 36 Fed. Reg. 24,201 (1971).

128 N.Y. Times, Dec. 21, 1971, at 53, col. 4 (city ed.). For the new currency parities, see Wall Street Journal, Dec. 21, 1971, at 3, col. 4 (Midwest ed.).

129 See N.Y. Times, Dec. 8, 1971, at 1, col. 4 (city ed.) (statement of Lord Carrington, Chairman of NATO's Eurogroup, consisting of the defense ministers of the member nations). 
calling attention to the "grave danger" the preference system represented for the most-favored nation principle. ${ }^{130}$ Particular stress was placed on the expansion of the system through the negotiations of the EEC with the free trade area countries not planning to enter the Common Market: Austria, Portugal, Sweden, and Switzerland. ${ }^{131}$ The United States estimated that the new round of preferences would cost $\$ 200-\$ 300$ million in exports. ${ }^{132}$

Although the United States did not publicly connect the preference issue with the removal of the surcharge, the implied connection was not overlooked by the EEC, which rejected the United States proposal of a GATT statistical study of the effects of preferences ${ }^{133}$ and flatly stated that there would be no discussion of preferences until the surcharge was removed. ${ }^{134}$

At the first Group of Ten meeting in Rome in late November, Secretary Connally first indicated that the United States might devalue as part of an exchange rate realignment. ${ }^{136}$ This "concession" was joined with the demand that "tangible progress"137 on "short-term" trade issues, ${ }^{138}$ including preferences, was a condition for surcharge removal. Although the preference issue was now joined to the surcharge, the "tangible progress" and "short-term" criteria indicated that actual or fundamental changes in the system might not be required.

In the subsequent trade talks between U.S. Special Rep. for Trade Negotiations William D. Eberle and EEC Commr. Ralf Dahrendorf, discussion focused on one aspect of the preference system, the citrus agreements. However, the United States demand that it pay the same tariff as Spain and Israel, ${ }^{139}$ which would have greatly impaired the

130 N.Y. Times, Nov. 20, 1971, at 41, col. 2 (city ed.) (statement of Herbert F. Propps, United States negotiator at the GATT).

131 See N.X. Times, Nov. 24, 1971, at 49, col. 4 (city ed.) (statement of Special Rep. for Trade Negotiations William D. Eberle).

132 N.Y. Times, Nov. 9, 1971, at 69, col. 2 (city ed.).

133 N.Y. Times, Nov. 26, 1971, at 59, col. 1 (city ed.). The United States stated that trade preferences had so proliferated that they had become the rule instead of an exception to the most-favored nation principle.

134 Id. See also N.Y. Times, Nov. 27, 1971, at 43, col. 3 (city ed.).

135 See N.Y. Times, Dec. 8, 1971, at 95, col. 6 (city ed.) (report on trade preferences).

136 N.Y. Times, Dec. 2, 1971, at 1, col. 7 (city ed.). This suggestion came in the form of a "hypothetical" posed by Secretary Connally when he asked the Group what it would do if the United States devalued the dollar by ten percent.

137 Id.; see N.Y. Times, Dec. 3, 1971, at 69, col. 2 (city ed.) (statement of Secretary Connally).

138 N.Y. Times, Dec. 8, 1971, at 95, col. 6 (city ed.); cf. N.Y. Times, Dec. 2, 1971, at 1, col. 7 (city ed.).

139 N.Y. Times; Dec. 9, 1971, at 78, col. 1 (city ed.). In one of the few examples of concessions to the United States on the preference issue, the EEC had reduced its tariff from 
value of the association agreement and put pressure on the preferences of Tunisia and Morocco, ${ }^{140}$ was resisted by Commissioner Dahrendorf, who noted that France had not agreed to a mandate on such issues ${ }^{141}$ and stated that insistence on trade concessions could endanger agreement on currency realignment. ${ }^{142}$

French consent to a mandate was secured only after President Nixon met with President Pompidou of France in the Azores on December 14, when the United States announced its intention to devalue as part of currency realignment. However, no French commitment to grant actual concessions was obtained. ${ }^{143}$ Thus, although Secretary Connally continued to insist on actual concessions, ${ }^{144}$ other Administration statements hedged between requiring actual concessions ${ }^{145}$ and tangible progress. ${ }^{148}$ Moreover, it became clear that devaluation and not surcharge removal would be the condition even for tangible progress ${ }^{147}$ when French Finance Minister Giscard d'Estaing indicated that this was the French understanding of the Azores agreement. ${ }^{148}$

Although a mandate for trade discussions issued, its scope was quite limited, precluding discussion of the United States demand for an end to "European special trading privileges" and restricting discussion on citrus preferences to the possibility of an EEC tariff reduction for the United States of an amount less than that granted to the Mediterranean

fifteen to eight percent on oranges entering the EEC from June 1 to September 30, 1971, the period when eighty percent of the United States crop was exported. The reasons for the concession, which was made on July 27,1971 , before the surcharge was imposed, remain unclear, as do the effects on the preference agreements with the Mediterranean states. See 2 CCH Comm. MKT. REP. I 9447 (1971). See also N.Y. Times, Dec. 8, 1971, at 95, col. 2 (city ed.).

140 See text at notes 57-58 supra.

141 N.Y. Times, Dec. 9, 1971, at 73, col. 1 (city ed.).

142 N.Y. Times, Dec. 10, 1971, at 65, col. 1 (city ed.). Commissioner Dahrendorf stated, "If this is the last word then a realignment of currencies isn't possible."

143 N.Y. Times, Dec. 15, 1971, at 1, col. 8 (city ed.). The text of the joint statement, in relevant part, was as follows:

Aware of the interest of measures involving trade for a lasting equilibrium of the balance of payments, President Pompidou confirmed that France, together with the Governments of the other countries which are members of the European Economic Community, was preparing the mandate which would permit the imminent opening of negotiations with the United States in order to settle the short-term problems currently pending and to establish the agenda for the examination of fundamental question[s] in the area of trade.

Id. at 48, col. 1 .

144 Wall Street Journal, Dec. 16, 1971, at 3, col. 2 (Midwest ed.).

145 Id.

146 N.Y. Times, Dec. 16, 1971, at 44, col. 1 (city ed.).

147 Compare N.Y. Times, Dec. 17, 1971, at 61, col. 1 (city ed.) (Treasury Department's precondition for surcharge removal) with Wall Street Journal, Dec. 16, 1971, at 3, col. 2 (Midwest ed.) (Secretary Connally's precondition for devaluation).

148 N.Y. Times, Dec. 17, 1971, at 61, col. 1 (city ed.). 
preference recipients. ${ }^{149}$ When President Nixon announced agreement on currency realignment on December 18 at the Washington Group of Ten meeting, ${ }^{150}$ indicated on December 19 that the surcharge would be removed, ${ }^{151}$ and effected its removal on December $20,{ }^{152}$ neither actual concessions nor tangible progress had been achieved on preferences or other trade issues.

The United States sought to preserve a bargaining counter for inducement of trade concessions by stating that devaluation-an increase in the price of gold from thirty-five to thirty-eight dollars per ouncewould not be sought from Congress unless trade concessions were forthcoming. ${ }^{153}$ Without an accompanying commitment by the United States to convert dollars for gold, which is highly unlikely, it is questionable whether this symbolic devaluation will be a sufficient inducement. It seems far more likely that trade issues can be resolved only through a "Nixon Round" of negotiations in which the United States will have to make trade concessions of its own to produce any EEC concessions. ${ }^{154}$

Thus, throughout the negotiations for removal of the surcharge, the EEC displayed unwillingness to make any significant concessions on the trade preference issue and was able finally to secure removal in exchange only for currency realignment. Its position changed imperceptibly with major United States policy changes: following the Rome meeting, the EEC discussed preferences, but without a mandate even though the United States had indicated that it might devalue; following the Azores meeting, at which the United States said it would devalue, France consented to a mandate, but quite narrow in scope; and following the surcharge removal, the EEC pledged only that it would continue to talk.

2. An Explanation of the Failure. The failure of the United States to obtain trade concessions in exchange for surcharge removal is traceable to two factors: the higher priority the United States placed on currency realignment and the limited leverage achieved by the imposition of the surcharge.

\footnotetext{
149 Id. at 61, col. 4 .

150 N.Y. Times, Dec. 19, 1971, at 1, col. 2 (city ed.).

151 Wall Street Journal, Dec. 20, 1971, at 1, col. 6 (Midwest ed.).

152 N.X. Times, Dec. 21, 1971, at 1, col. 4 (city ed.).

153 Wall Street Journal, Dec. 20, 1971, at 1, col. 6 (Midwest ed.). In announcing the removal of the surcharge, President Nixon implied that some agreements on trade had been reached: "This first step having been taken, we can now move on to the trade areas and the monetary areas in which agreement was also reached over the weekend." N.Y. Times, Dec. 21, 1971, at 53, col. 4 (city ed.). This seems to be an overstatement, however, since it was reported that Secretary Connally was trying to enlist British support "for help" to persuade the EEC to end restrictive trade practices such as preferences. This initiative implies that no agreement had yet been reached.

154 Cf. Wall Street Journal, Dec. 20, 1971, at 3, col. 2 (Midwest ed.).
} 
The priority that the United States put on currency realignment was clear from the manner in which it pursued negotiations-first seeking currency realignment and then seeking trade concessions. ${ }^{155}$ This priority is justified by the disparity in the values of currency and trade adjustment. A weighted eleven percent revaluation of foreign currencies would produce an $\$ 8.8$ billion improvement in the United States balance of payments, according to an International Monetary Fund formula, ${ }^{156}$ whereas the loss from trade preferences would probably be less than $\$ 1$ billion. ${ }^{157}$ Moreover, the $\$ 1$ billion figure is included in the balance-of-payments adjustment since prior imbalances are attributable in part to these preferences.

The leverage achieved by the imposition of the surcharge inhered in the ability of the United States to inflict trade losses on other countries, which in turn could cause unemployment in the export sector and occasion political demands in those countries to comply with United States demands. Thus, after the surcharge was imposed the Japanese Ministry of Trade estimated that the combined effect of the surcharge and the appreciation of its exchange rate could lead to a $\$ 2.4$ billion loss in trade. ${ }^{158}$ Similarly, an EEC study concluded that its $\$ 2$ billion trade surplus would be eliminated. ${ }^{159}$ European authorities also feared that the surcharge would contribute to a recession. ${ }^{160}$ An EEC report stated that, at a minimum, "United States policy will aggravate a situation already deteriorating." 161

This potential leverage was, nevertheless, limited by a number of factors. First, the surcharge in combination with the closing of the gold window could not easily produce realignment of exchange rates. Foreign governments could stop such adjustment through exchange controls, typified by the French two-tier system, or through market

155 The trade issue began to surface only in late November or early December, 1971, after there had been an appreciable float in currency rates-particularly the mark and the yen-and after the United States had indicated that it would "contribute" to realign. ment by devaluing the dollar. The timing of the monetary and trade issues is another indication of their relative priorities.

156 N.Y. Times, Nov. 8, 1971, at 63, col. 1 (city ed.).

157 This figure is based on the fact that $\$ 750$ million in present United States exports compete with goods receiving trade preferences and that an additional $\$ 200-\$ 300$ million would be affected by entry of the European free trade area states into preference agreements. See notes 45,131 supra.

158 N.Y. Times, Sept. 9, 1971, at 61, col. 1 (city ed.).

159 N.Y. Times, Sept. 21, 1971, at 29, col. 1 (city ed.).

160 Thus, Italian authorities reported that production was off seven percent and that prices were up seven percent. N.Y. Times, Oct. 18, 1971, at 59, col. 1 (city ed.). German business leaders were also extremely concerned about economic prospects. N.Y. Times, Oct. 26, 1971, at 59, col. 3 (city ed.).

161 N.Y. Times, Oct. 25, 1971, at 1, col. 4 (city ed.). 
intervention. ${ }^{162}$ Although the surcharge contributed to pressure on governments, a decision to allow revaluation through an upward float would only intensify such pressure since the prices of exports would increase by ten percent plus the appreciation of the currency. Since the surcharge could not easily produce currency realignment, the United States was forced to limit the conditions for its removal to such realignment.

Second, the longer the surcharge remained, the greater was the pressure on foreign countries to retaliate by imposing their own trade restrictions. Thus, Canada threatened to subsidize partially its export industry ${ }^{163}$ and Denmark imposed a ten percent surcharge of its own. ${ }^{164}$ Although the EEC did not retaliate, there were continuous low-level threats that it might do so. As Commisioner Dahrendorf put it, "If the American surcharge remains in effect, there will be great pressure from certain industries and trade unions to apply protectionist measures."168

Third, to obtain maximum leverage, the Nixon Administration was required to make it credible that the surcharge could be removed in the face of protectionist demands that it be made permanent. ${ }^{168}$ Such credibility was likely to decrease over time as companies raised prices to levels which were competitive only while the surcharge was in effect. This possibility was minimized to some extent, however, by the Price Commission's allowance of price increases only to reflect increased

162 Thus, the French did not permit any adjustment of exchange rates on commercial transactions and instead intervened in the market. N.X. Times, Sept. 1, 1971, at 1, col. 2 (city ed.). Only the rates on other transactions in foreign currency, which comprise twentyfive percent of all transactions, were permitted to float. N.Y. Times, Aug. 21, 1971, at 1, col. 6 (city ed.). This kind of market intervention, especially in the forward market, can block exchange rate adjustment as Iong as central banks are willing to absorb United States dollars. Cf. P. Einzig, Foreign Exchange Crisis 147-48 (2d ed. 1970).

163 N.Y. Times, Sept. 8, 1971, at I, col. 3 (city ed.).

164 N.Y. Times, Oct. 20, 1971, at 73, col. 1 (city ed.). This response was significant from a political viewpoint in that it was adopted by the newly elected Social Democrats in their first day in office. The less-developed countries were exempted from coverage.

165 N.Y. Times, Oct. 23, 1971, at 45, col. 1 (city ed.).

166 Indeed, some members of Congress seemed to view the purpose of the surcharge as protection of American industries rather than achievement of trade liberalization or exchange rate adjustment. They preferred that the surcharge be permanent. NEP Hearings, supra note 125, at 12-13 (remarks of Sen. Paul Fannin). Most members of industry viewed the surcharge in the same manner. Hearings on the Revenue Act of 1971, H.R. 10947, Before the Senate Comm. on Finance, 92d Cong., Ist Sess. (1971) (testimony of automobile dealers representative at 117 , steel industry representative at 334-35, machine tool industry representative at 418). See also N.Y. Times, Nov. 16, 1971, at 65, col. 2 (city ed.) (statement of Undersec. of State for Economic Affairs Nathaniel Samuels before the Fiftyeighth National Foreign Trade Convention indicating that protectionist forces would become irresistible unless there were a balance-of-payments correction through currency realignment). 
$\operatorname{costs}^{167}$ and the consequent apparent exclusion of surcharge-related increases. Thus, in the auto industry, which was given a more than 20 percent margin of protection through a surcharge of 10 percent and the float of the yen and mark of more than 10 percent, price increases ranged from 2.5 to 4.5 percent. ${ }^{108}$

Fourth, the leverage of the surcharge was limited by its bluntnessit was to be applied to and removed from all countries at the same time since the Administration opposed more selective use. ${ }^{169}$ This policy had the effect of limiting the leverage of the surcharge against all countries to its leverage against that country against which it had the least leverage. Thus, even if Japan might have granted trade concessions as well as adjusted exchange rates, it might have anticipated that France would only adjust rates and demand surcharge removal directly thereafter. Once France agreed, the surcharge would have been removed from all countries regardless of the fact that more concessions might have been obtained from Japan.

Fifth and most important, the United States could not have effectively removed the surcharge from any given EEG member even if it had desired to do so. When the United States hinted that it would remove the surcharge from Germany because it had allowed its currency to appreciate, the EEC collectively viewed this possibility as a divideand-conquer strategy and resisted it. ${ }^{170}$ Thus, France, whose minimal trade with the United States and independence from NATO made it least susceptible to surcharge leverage ${ }^{171}$ and consequently least likely to favor trade concessions to remove the surcharge, blocked the possibility of meaningful trade negotiations.

These limiting factors resulted in the failure of the retaliatory strategy, at least as it related to trade. As suggested previously, one might view the correction of the imbalance of payments as compensating for the loss of trade. Two major differences between the two alter-

167 Price Commission Regulations subpt. A, § 300.12, 86 Fed. Reg. 21,792 (1971).

$168 \mathrm{CCH} 1971$ Economic Controls $\$ 9934$. American Motors and General Motors were granted 2.5 percent price increases; Ford, 2.9 percent; and Chrysler, 4.5 percent.

168 The reason for not adopting a more selective application remains unclear. The premise of across-the-board application was supplied by President Nixon in his speech announcing the imposition of the surcharge: "The import tax is a temporary action. It isn't directed against any other country." 65 DEP'T STATE BuLL. 253, 255 (1971). The principle of nonselectivity becomes more difficult to understand in light of the fact that the actions of only a very few countries affected the removal of the surcharge.

170 See N.Y. Times, Oct. 19, 1971, at 61, col. 3 (city ed.); N.Y. Times, Oct. 20, 1971, at 73, col. 2 (city ed.).

171 Four percent of French exports were to the United States. This represented less than one percent of the French gross national product. N.Y. Times, Dec. 15, 1971, at 91, col. 2 (city ed.). 
natives exist, however. First, the new currency rates will generally benefit United States exporters and domestic producers, whose goods will become more competitive with higher-priced imports. Trade concessions, on the other hand, would have benefited specific exporters who are discriminated against. These exporters, moreover, will not benefit from the currency realignment since trade measures such as the variable levy used by the EEG can nullify the price advantage resulting from revaluation of foreign currencies. ${ }^{172}$ This points to the second major difference. Elimination of trade discrimination would have produced a long-run adjustment in the trade balance, whereas the fixedrate currency realignment will compensate only temporarily for trade discrimination until a future realignment occurs.

3. Significant Costs. Three significant costs of the surcharge policy are of importance: the breaking of international legal obligations by the United States, the negative reaction of the less-developed countries, and the probability of a more suspicious attitude by the EEG toward the United States in the future.

In order to apply the surcharge, the United States was obliged to violate the two principal international agreements regulating trade and monetary policy-the GATT and the International Monetary Fund Agreement. ${ }^{173}$ The concern here is primarily with the GATT.

The United States sought to justify its surcharge under article XII of the GATT, which permits a contracting party, subject to a number of restrictions, to "safeguard its external financial position and its balance of payments [by] restrict[ing] the quantity or value of merchandise permitted to be imported ...." After GATT review, it was determined that this article could not justify the surcharge because it envisioned only quantitative restrictions, and not the withdrawal of tariff concessions, as an appropriate response to balance-of-payments problems. According to the Working Party, the United States argument

172 Thus, the levy can be raised to a new level to continue to keep out United States exports when local EEC prices are lower than the support price. See Dam, supra note 58, at 217. The EEC planned to make this adjustment and rejected United States demands that the levy be frozen at its prerealignment rate. See N.Y. Times, Dec. 14, 1971, at 67, col. 1 (city ed.) (statement of Sicco Mansholt, Chief Farm Specialist of the EEC).

173 The Agreement, known as the Bretton Woods Agreement, requires member countries to establish par values for their currencies based on gold or on the United States dollar of specified gold content. Fluctuations from par in the spot market must be within one percent of the fixed rate. International Monetary Fund Agreement, July 22, 1944, art. IV, § 3(i), 60 Stat. 1401 (1946), T.I.A.S. No. 1501 (effective Dec. 27, 1945). Changes in par values must be made after consultation with the Fund and only to correct a "fundamental disequilibrium" (an undefined term). Id. art. IV, §§ 5(a)-(b). The United States demanded that certain governments not fix their rates at past parities and instead encouraged shortterm floating, the opposite of a fixed-rate system. 
that a surcharge is less damaging to world trade than are quantitative restrictions was not sufficient justification for raising tariffs. ${ }^{174}$

The GATT was especially concerned with the effects of the surcharge on the less-developed countries. It concluded that, "in spite of the exemption of many raw materials and primary products normally exported by them, the import surcharge significantly affected the export interest of developing countries." Pursuant to this conclusion, the Working Party indicated its desire that the United States explore the possibility of exemptions for such countries. ${ }^{175}$ This indicates that GATT approval or reservation of judgment would have been more likely had the United States raised tariffs on a selective basis.

Latin America, the less-developed area of greatest interest to the United States, reacted strongly against the imposition of the surcharge. ${ }^{176}$ Although the surcharge affected only 19.7 percent of its exports, it applied to those semi-manufactured and processed goods critical to any long-term improvement in Latin America's trade position. ${ }^{177}$ Mexico, for example, one of the more developed of the Latin American countries, had 38 percent of its exports covered by the surcharge. ${ }^{178}$ Moreover, not only were many Latin American exports subject to additional duties in their principal market, but also the trade preferences which they were promised did not materialize. Nevertheless, the Administration refused to exempt Latin America from the surcharge. ${ }^{179}$

The disaffection of Latin American countries with United States trade policy is reflected in a new series of trade negotiations between the EEC and Latin America. In November, 1971, the EEC was in the process of concluding a three-year trade agreement with Argentina, had begun negotiating with Uruguay, and was expected to open negotiations with Brazil. ${ }^{180}$ Moreover, as previously indicated, Latin Amer-

174 The United States notified GATT of the imposition of the surcharge on August 16, 1971. GATT, Press Release No. 1087 (Aug. 16, 1971). GATT then established the Working Party to examine the compatibility of the surcharge with the Agreement. GATT, Press Release No. 1088 (Aug. 26, 1971). Its conclusions were issued in GATT, Press Release No. 1090 (Sept. 16, 1971).

175 GATT, Press Release No. 1090 (Sept. 16, 1971). During the GATT review, the EEC reserved its right to claim reparations for the United States action, N.X. Times, Aug. 25, 1971, at 1, col. 6 (city ed.), and the less-developed countries requested exemption, N.Y. Times, Aug. 26, 1971, at 32, col. 1 (city ed.).

176 N.Y. Times, Sept. 2, 1971, at 47, col. 2 (city ed.).

177 N.Y. Times, Sept. 14, 1971, at 25, col. 1 (city ed.) (statement of Under Secretary Samuels).

178117 Cong. REc. S18,485 (daily ed. Nov. 13, 1971) (remarks of Sen. James Buckley). 179 N.Y. Times, Sept. 20, 1971, at 8, col. 5 (city ed.) (statement of Asst. Sec. of State for International Affairs Charles A. Meyer).

180 N.Y. Times, Nov. 9, 1971, at 69, col. 2. 
ican countries were already participating in the EEC's general preference plan. ${ }^{181}$

Finally, the EEC is likely to regard United States objectives with increasing suspicion. Many European leaders suspect that the United States no longer views the EEC's economic strength in strictly positive terms. ${ }^{182}$ Particular suspicion was roused by such divide-and-conquer aspects of United States policy as the hint of selective removal of the surcharge. Moreover, the United States interest in dismantling preferences is being viewed increasingly in political terms. Thus, Commissioner Dahrendorf viewed the demand for elimination of the citrus preferences as an attack on the political interests of the EEC in the Mediterranean, stating, "We feel we have the responsibility there that the United States has in the rest of the world."183 An even stronger view was taken by Commr. Sicco Mansholt, who stated, "We do more with our preferences than six, seven or even eight fleets in the Mediterreanean."184 One suspects that this cost was unavoidable if the United States was to make any meaningful trade demands. The pressure tactics associated with the surcharge policy, however, intensified the EEC reaction.

4. A Policy Alternative. If the United States were committed to employ a retaliatory policy, it might have adopted a selective and measured response against major trading countries and the EEC by gradually increasing tariff rates until its objectives had been achieved. This policy would have been just as likely to produce monetary realignment as would an across-the-board surcharge because it would have been addressed to those countries whose exchange rates were undervalued. It would, moreover, have had the following advantages over the surcharge: (1) it would have avoided opposition from the less-developed countries-in fact, since tariffs of most developed countries would have been raised, it would have constituted a comparative trade preference; (2) since the tariff would have been gradually increased and selectively applied, it would have minimized the protection of American industries; (3) it might have been approved by GATT; and (4) it could have been removed selectively, thus increasing its leverage on countries other than those within the EEC.

The only additional cost of such a policy might have been trade diversion resulting from discriminatory rates. This possibility would

181 See text at note 119 supra.

182 Frankel, U.S. and Common Market: Doubt, Suspicion, N.X. Times, Dec. 18, 1971, at

8, col. 1 (city ed.).

183 N.Y. Times, Dec. 17, 1971, at 61, col. 4 (city ed.)

184 Id. 
have been minimized, however, due to the difference in goods exported by the developed and less-developed countries and the short-term duration of the policy.

Finally, as will next be demonstrated, the policy of selective retaliation was the only one that the President had the legal authority to undertake. The surcharge policy represented a fundamental disregard by the Nixon Administration for the limitations on presidential power established by Congress and thus carried with it an institutional cost as well.

\section{B. Authority for Imposition of the Surcharge}

The United States response to EEC trade preferences did not rest on the authority of domestic statutory law until the imposition of the surcharge. Thus, challenges under the GATT only assumed that the EEC was bound by the Agreement, ${ }^{185}$ and its own preference policies assumed that new legislation would be needed. ${ }^{186}$

The surcharge, on the other hand, was effected by a Presidential Proclamation providing for withdrawal of up to ten percent of prior tariff concessions granted in trade agreements. ${ }^{187}$ Its operation can be understood by an examination of the hypothetical situation illustrated in table 1 .

TABLE 1

EFFect of the SURcharge on TARIFF Rates

(by percent)

\begin{tabular}{cccc}
\hline Product & $\begin{array}{c}\text { Trade Agreement } \\
\text { Rate }\end{array}$ & $\begin{array}{c}\text { Statutory } \\
\text { Rate }\end{array}$ & $\begin{array}{c}\text { Rate after } \\
\text { Surcharge }\end{array}$ \\
\hline A & 20 & 40 & 30 \\
B & 20 & 30 & 30 \\
C & 20 & 25 & 25 \\
D & 20 & 20 & 20 \\
\hline
\end{tabular}

In the case of product $\mathrm{A}$, where the size of the concession (the difference between the trade agreement rate and the statutory rate) is twenty

185 Whether the United States is bound by the GATT is not, therefore, at issue. Cf. Jackson, The GATT in U.S. Domestic Law, 66 MrCH. L. REv. 249 (1967).

186 See text at note 123 supra.

187 Pres. Proclamation No. 4074, pt. B(2), 36 Fed. Reg. 15,724-25 (1971), provides in relevant part:

Such proclamations [those granting concessions under trade agreements] are suspended only insofar as is required to assess a surcharge in the form of a supplemental duty amounting to 10 percent ad valorem ... provided, however, that if the imposition of an additional duty of 10 percent ad valorem would cause the total duty or charge payable to exceed the total duty or charge payable at the rate prescribed in column 2 of the Tariff Schedules of the United States [the statutory rate], then the column 2 rate shall apply. 
percent, ten of the twenty percent may be suspended. For product $B$, where the concession is ten percent, the entire concession may be suspended. For product $\mathbf{C}$, where the concession is five percent, only a five percent concession may be suspended. And for product $D$, on which no previous concession was granted, the tariff must remain unchanged. Thus, the tariff may be increased by ten percent above the trade agreement rate or statutory rate, whichever is lower. Operationally, it should be clear that raising rates from their present level or suspending prior concessions are equivalent acts-two sides of the same coin.

The Proclamation delegates to the Secretary of the Treasury the power to make certain exemptions to the above principles. It provides:

The Secretary may from time to time take action to reduce, eliminate or reimpose the rate of additional duty herein or to establish exemption therefrom, either generally or with respect to an article which he may specify either generally or as the product of a particular country, if he determines that such action is consistent with safeguarding the balance of payments position of the United States. ${ }^{188}$

This power was used to exempt goods for which no duty was paid prior to the imposition of the surcharge, goods imported subject to tariff quotas, and goods already in stock when the surcharge was imposed.189

The Proclamation purports to base authority for the action on the powers given the President "by the Constitution and the statutes, including but not limited to the Tariff Act of 1930, as amended, and the Trade Expansion Act of 1962 . . . ."190 The central proposition advanced in this part of the comment is that the imposition of the surcharge by the President was illegal in that the act exceeded his constitutional and statutory authority to raise tariffs. This authority, it

188 Id. subpt. C(4)(a), 36 Fed. Reg. 15,725.

189 See 36 Fed. Reg. 16,597 (1971) (exempting articles imported before 12:01 A.M., August 16, 1971); 36 Fed. Reg. 17,057 (1971) (exempting certain meats (item numbers 106.10, 106.20 of Tariff Schedules of the United States, 19 U.S.C. \& 1202 (1970)) and items subject to import quotas under section 22 of the Agricultural Adjustment Act, 7 U.S.C. \$ 624 (1970); under the Sugar Act of 1948, 7 U.S.C. \$ 1100 et seq. (1970); under section 232 of the Trade Expansion Act of 1962, 19 U.S.C. $\S 1862$ (1970) (this section allows quotas to be imposed on items whose unlimited importation threaten the national security and applies presently to oil); and pursuant to the Long-Term International Cotton Textile Agreement, 33 Fed. Reg. 582 (1968)). Moreover, all articles which were duty-free before the imposition of the surcharge were exempted because the surcharge applied only to "dutiable" items. Pres. Proclamation No. 4074, 36 Fed. Reg. 15,724 (1971). See also Explanatory Material of the White House Press Secretary, Aug. 15, 1971, in CCH 1971 ECONOMIC Controls If 5005.

190 Pres. Proclamation No. 4074, para. 5, 36 Fed. Reg. 15,725 (1971). 
will be argued, is restricted to those cases in which tariffs are raised in response to significant discriminatory actions by other countries against United States exports. The surcharge cannot be such a response since it applies to the exports of all countries, not merely those which have taken discriminatory action.

1. Constitutional Authority. If the phrasing of the surcharge authority was intended to indicate that the Constitution gives the President power to set tariffs without congressional authority, the conclusion is clearly wrong. The Constitution vests in Congress the power "to lay and collect taxes, duties, imports and excises" and "to regulate commerce with foreign nations."191 Pursuant to this power, Congress has historically exercised legislative authority over the entire field of foreign trade regulation, including the imposition of tariffs. ${ }^{192}$ Prior to the passage of the Trade Agreements Act of 1934, Congress established the tariff rates itself. ${ }^{193}$ Since that date Congress has delegated to the President the power to set tariffs, but only within given guidelines.

The Supreme Court has approved this delegation of power with the proviso that Congress provide a standard to govern the exercise of Presidential discretion. ${ }^{194}$ As Chief Justice Taft stated in Hampton \& Co. v. United States, ${ }^{195}$ "If Congress shall lay down by legislative act an intelligible principle to which the person or body authorized to fix such rates is directed to conform, such legislative action is not a forbidden delegation of legislative power." Even with proper delegation, however, if the President should violate the guidelines, his act would be without authority and unconstitutional. ${ }^{196}$ If the statutes could be

101 U.S. ConsT. art. I, \$ 8.

192 See K. Mackenzie, Tariff-Making and Trade Policy in the U.S. and Canada 1-33 (1968); S.D. Metzger, Trade Agreements AND the KenNedy Round 11-18 (1964). See generally F.W. TAussig, The TARIfF History of the UNited States (8th ed. 1931).

193 S.D. METZCER, supra note 192, at 12-14.

$194 \mathrm{~K}$. MACKENZIE, supra note 192 , at 5-7 and cases cited therein.

195276 U.S. 394, 409 (1927).

196 Falcon Sales Co. v. United States, 199 F. Supp. 97 (Cust. Ct. 1961); United States v. Schmidt Pritchard \& Co., 47 C.C.P.A. 152, cert. denied, 364 U.S. 919 (1960). Neither the President's power as Commander-in-Chief nor his unique executive powers includes the power to make law. Youngstown Sheet \& Tube Co. v. Sawyer, 343 U.S. 579 (1952). "The President's order does not direct that a congressional policy be executed in a manner prescribed by Congress-it directs that a presidential policy be executed in a manner prescribed by the President." Id. at 588. That the order itself set out the President's reasons for adopting his policy was taken as indicative of its attempt to achieve statutory status.

Where rule making pursuant to a law delegating power ends and law making by the President begins is an issue about which opinions vary greatly, and since Youngstown the Supreme Court has accordingly sought nonconstitutional grounds on which to dispose of cases raising the question. See, e.g., Kent v. Dulles, 357 U.S. 116, 128 (1958). Compare 
interpreted to authorize the surcharge, then they might themselves be challenged as an unconstitutional delegation of authority. ${ }^{197}$ As a review of the statutes will indicate, one or the other of these consequences follow from the imposition of the surcharge.

2. Statutory Authority. As indicated in the Proclamation, the statutory authority for the surcharge is based on two legislative enactments: section 350(a) of the Tariff Act of 1930, as amended, ${ }^{198}$ and the Trade Expansion Act of 1962.199 Each enactment contains a number of provisions empowering the President to raise tariffs, some of which overlap. The following analysis will be restricted to those provisions which offer colorable justification for the surcharge. ${ }^{200}$ The first set of provi-

Arizona v. California, 373 U.S. 546, 626-27 (1963) (Harlan,' J., dissenting in part), with Zemel v. Rusk, 381 U.S. 1, 2 (1965) (Black, J., dissenting) and United States v. Sharpnack, 355 U.S. 286, 297 (1958) (Douglas, J., dissenting).

197 If the statute is construed as authorizing the imposition of the surcharge by the President, the possibility that the statute unconstitutionally delegates that power must be considered. Professor Davis suggests that the nondelegation doctrine has little current vitality: "The vaguest of standards are held adequate, and various delegations without standards have been upheld." I K.C. Davis, Administrative LAw Treatise ff 2.01, at 76 (1958). The only two cases in which congressional delegations to public authorities were held invalid, he argues, rested on special factors not likely to recur. A.L.A. Schechter Poultry Corp. v. United States, 295 U.S. 495 (1935) (excessively broad delegation); Panama Refining Co. v. Ryan, 293 U.S. 388 (1935) (exceptional executive disorganization). Professor Jaffe, reaching much the same conclusion, notes that "not a single judge of the Court .. . has ever suggested that there are no limits on the power to delegate." L. JAFFE, Judicial Control of Administrative Action 68 (1965). Extreme circumstances, such as "a new depression," might force the issue, he suggests. Id. at 72.

Neither the case law nor the commentaries, however, speaks meaningfully to the delegation said to be involved in the power to impose the surcharge. Imposition is essentially a discrete action, complete in itself. It is not elaborated by individual decisions and interpretations any more than would the same decision made directly by Congress. Rather than focusing on the due process issues typically involved in disputed delegations, therefore, attention must be confined here to the separation-of-powers issue. The general principle that power is reposed by the Constitution in a particular branch of government must, of course, be reconciled with modern realities. But is it possible to argue that the President must be able to respond to both aggression and economic trends with similar dispatch?

19819 U.S.C. § 1351 (1970), formerly ch. 474, § 1, 48 Stat. 943 (1934). The amended version delegated certain authority to the President to enter into trade agreements and make concessions thereunder or to raise rates. It will hereinafter be referred to as section 350 (a) of the Tariff Act. For the legislative history of the 1934 amendment, see Sayre, The Constitutionality of The Trade Agreements Act, 39 ColUM. L. REv. 751 (1939); Note, The Trade Agreements Act of 1934, 46 YALE L.J. 647 (1937).

19919 U.S.C. $\$ \S 1801-1991$ (1970).

200 Three provisions of the Act-sections 201, 232, and 35I, 19 U.S.C. $\$ \S 1821,1862$, 1981 (1970)-seem clearly inapplicable. Under section 201(a)(2), entitled "Basic Authority for Trade Agreements," the President, whenever he "determines that any existing duties or other import restrictions of any foreign country or the United States are unduly burdening," may raise tariffs by proclamation "as he determines to be required or appropriate to carry out any such trade agreement." The surcharge cannot, however, be said to be "appropriate to carry out a trade agreement" but rather does just the 
sions which meets this requirement is section 350(a) of the Tariff Act ${ }^{201}$ and section 252 of the Trade Expansion Act. ${ }^{202}$ Both deal with the power of the President to respond to discriminatory trade measures.

a. Section 350(a): Selective retaliation. Section 350(a) of the Tariff Act was added by amendment in 1934. It provides:

[T] he President, whenever he finds as as a fact that any existing duties or other import restrictions of the United States or any foreign country are unduly burdening and restricting the foreign trade of the United States and that the purpose above declared will be promoted by the means hereinafter specified, is authorized from time to time-

(A) To enter into foreign trade agreements with foreign governments or instrumentalities thereof. . . .

(B) To proclaim such modifications of existing duties and other import restrictions or such continuance, and for such minimum periods, of existing customs or excise treatment of any article covered by foreign trade agreements, as are required or appropriate to carry out any foreign trade agreement that the President has entered into hereunder.

opposite by suspending the provisions of trade agreements. The section would more appropriately be used to reinstate concession rates. Hearings on H.R. 9900 Before the House Comm. on Ways \& Means, 87th Cong., 2d Sess. 3871-72 (1962) (statement of Under Sec. of State George Ball) [hereinafter cited as 1962 House Hearings]. See also NEP Hearings, supra note 125 , at 24 .

Under section 282, entitled "Safeguarding National Security," following an investigation by the Director of the Office of Emergency Planning (OEP) which determines that the importation of a certain good in certain quantities may impair the national security, the President "shall take such action, and for such time, as he deems necessary to adjust the imports of such article and its derivatives ...." The scope of this section on its face can apply only to a limited number of imported items, such as petroleum. The surcharge, on the other hand, applies to many items which even the most dedicated protectionist would find difficult to argue were impairing the national security. Moreover, action by the President under this section requires a fact finding by the OEP Director, which clearly was not made in this case. See 1962 House Hearings, supra at 766-67.

Under section 351, pursuant to a finding by the Tariff Commission under section 301, 19 U.S.C. $\S 1901$ (1970), that "as a result in major part of concessions granted under trade agreements, an article is being imported into the United States in such increased quantities as to cause, or threaten to cause, serious injury to the domestic industry producing an article which is like or directly competitive with the imported article." The President may increase tariffs on the threatening goods. This provision is aimed at injury to domestic producers and not harm to the export industry, as is the case with trade preference systems and nontariff barriers, and thus seems not to apply to the imposition of the surcharge. Moreover, no petition has been addressed to the Tariff Commission to make such a finding on every article imported into the United States. See also U.S. Tariff Comm'n, Rules of Practice and Procedure, 27 Fed. Reg. 12,117 (1962).

20119 U.S.C. \& 1351 (1970).

20219 U.S.C. \$ 1882 (1970). 
In examining the legislative history of this provision, two general background points should be noted. First, although Congress did consider in detail the limitations that the amendment would place on presidential action, its consideration was prompted more by the fear that the President would lower rates rather than raise them. ${ }^{203}$ Nonetheless, the limitations on the power to raise accompanied the limitations on the power to lower tariffs. ${ }^{204}$ Second, whether a surcharge could be imposed was not discussed at all.

The essential provision of section 350(a) is that the President may raise tariffs "whenever he finds as a fact any existing duties or other import restrictions of . . . any foreign country are unduly burdening and restricting" United States trade. Thus, a foreign restriction and the undue burden were factual preconditions to and limitations on the exercise of presidential power.

The limiting features of this provision were quite apparent to Congress during consideration of the amendment. The House Report called foreign restrictions a "definite criterion" for presidential action: ${ }^{205}$ And, as Sen. Frederick Steiwer stated in the final Senate debate, only after a finding of foreign restrictions is made may the President act. More-

203 This arose from the fact that the main purpose of the bill was to give the President the authority to enter into trade agreements through which tariff rates would be lowered and trade expanded. As Sec. of State Cordell Hull stated: "[I]t is manifest that unless the Executive is given authority to deal with the existing great emergency somewhat on a parity with that exercised by the executive departments of so many other governments for purposes of negotiating and carrying into effect trade agreements, it will not be practicable or possible for the United States to pursue with any degree of success the proposed policy of restoring our lost international trade." Hearings on H.R. 8430 Before the House Comm. on Ways \& Means, 73d Cong., 2d Sess. 5-6 (1934) [hereinafter cited as 1934 House Hearings]. See also Message from the President of the United States: ReQUEST to Authorize the Executive to ENTER into Executive Commercial Agreements with Foreign Nations, H.R. Doc. No. 273, 73d Cong., 2d Sess. (1934). Throughout consideration of this bill, congressmen expressed concern over the possible impact of these lower rates on domestic industries. See 1934 House Hearings, supra at 73. Robert Lincoln O'Brien, Chairman of the Tariff Commission, stated: "[S]ince there seems to be no worry about the President's use of that power in raising tariffs, I will direct my remarks wholly to the President's use of the power . . . in lowering rates." Id.

204 One of the central issues during consideration of the legislation was whether Congress could delegate any power to the President to set tariff rates. See H.R. REP. No. 1000, 73d Cong., 2d Sess. (1934). The opponents of delegated power to lower rates found it difficult to support their position when they thought delegated power to raise rates was permissible. See 78 Cong. REc. 5345 (1934) (exchange between Reps. Samuel B. Hill and Harold Knutson).

205 H.R. REP. No. 1000, 73d Cong., 2d Sess. 14-15 (1934). See also 1934 House Hearings, supra note 203, at 293-302 (statement of Asst. Sec. of State Francis B. Sayre); Hearings on H.R. 8687 Before the Senate Comm. on Finance, 73 Cong., 2d Sess. 58 (1934) [hereinafter cited as 1934 Senate Hearings]. 
over, he stated, not all restrictions would permit presidential action, but only those "unduly burdening" to American trade. ${ }^{206}$

The limits within which presidential power was confined are made even clearer by one of the major amendments to the Senate bill. As introduced by the Administration in the House, the bill had provided that the President might act "whenever he finds that any existing duties or other import restrictions are unduly burdening and restricting the foreign trade of the United States or that the purpose above declared [to promote foreign trade] will be promoted by the use of the powers herein conferred . . . . "207 The amendment changed the "or" to an "and" to eliminate what Rep. Emmanuel Celler termed the "basket clause," 208 which would have served as a very loose control on the authority of the President. ${ }^{209}$

The circumstances surrounding the surcharge, however, did not meet the strict factual preconditions which must be met before the President may act under section 350(a). Although the surcharge was imposed against all countries, ${ }^{210}$ there is no evidence that a finding could reasonably be made that every country had restricted and unduly burdened United States trade. Under the section, such a finding must be made on a country-by-country basis since trade restrictions differ among countries.

\section{Although many countries have restrictions on United States trade, ${ }^{\mathbf{2 1 1}}$}

20678 Cong. Rec. 10,203 (1934).

207 H.R. 8430, 73d Cong., 2d Sess. (1934) (emphasis added).

20878 CoNG. REc. 5558 (1934). Representative Celler said that the original version of the bill gave

to the Executive the right to modify the existing duties within a 50-percent range. He has a right to impose import restrictions, he has the right to retaliate upon those countries which discriminate against American commerce, and as the bill reads "or for any other reason," which is a sort of basket clause, which increases the power the President has.

He can do almost anything in his discretion without let or hindrance, and these Id. powers are to be exercised by Presidential proclamation.

209 The express purpose of the amendment was to limit presidential power to respond only to foreign import restrictions. It was suggested for this purpose by James A. Emery of the National Association of Manufacturers. 1934 House Hearings, supra note 203, at 421; 1934 Senate Hearings, supra note 205, at 294. The Administration supported this limitation as the only "yardstick" for presidential action. 1d. at 99-100 (statement of Assistant Secretary Sayre). There was no opposition to the amendment on the Senate floor, and the House concurred in a 154-53 vote, 78 CoNG. Rrc. 10,636 (1934), with Rep. Robert Doughton terming the amendment a "limitation of power," $i d$. at 10,628.

210 The "finding of fact" requirement suggests that such a finding should be made public as an announced reason for presidential action.

211 "Duties and import restriction" are defined broadly in the amendment to section 350(c), 19 U.S.C. \& 1351 (c)(1) (1970), to include "(A) rate and form of import duties and 
many restrictions cannot reasonably be said to burden United States trade unduly. For example, a finding by the Presidential Commission on International Trade and Investment Policy that Sierra Leone imposes quantitative restrictions by requiring specific licenses for a "few products" and employs an "automobile valuation based on engine size which discriminates against high horsepower vehicles"212 can hardly support the conclusion that a decrease in automobile exports to Sierra Leone unduly burdens trade. If such a conclusion could be reached by the President, it would so dilute the factual preconditions in the amendment as to render them meaningless.

Finally, there is no reason to believe from the Proclamation or other statements of the Administration that the surcharge was based on any finding of foreign restrictions beyond those of the EEC and major trading nations. Instead, the thrust of Administration justification was the balance-of-payments problem. ${ }^{213}$

b. Section 252: Selective retaliation. The second statutory provision which relates to foreign restrictions is section 252 of the Trade Expansion Act. ${ }^{214}$ This section, entitled "Foreign Import Restrictions," establishes three different preconditions, each of which arguably allows the President to raise tariffs by withdrawing prior concessions. One might assume that this section would be most relevant in seeking a statutory

classification of articles, and (B) limitations, prohibitions, charges, and exactions other than duties, imposed on importation or imposed for the regulation of imports." This broad definition could include almost any kind of trade restrictions, perhaps even exchange controls. 1934 House Hearings, supra note 203, at 20-21 (statement of Secretary Hull). Thus, it is possible that the President, if a diligent search were made, could document at least one such restriction for every country in the world. An attempt at such documentation is already available. Pursuant to a recommendation to the President in 1970 to pursue negotiations to reduce nontariff barriers, the House Ways and Means Committee compiled an "inventory" of nontariff barriers employed by sixty-nine countries. 1 U.S. CoMm'N oN International Trade \& Investment Policy, Working Papers 677 (1971). An inventory could also be compiled of exchange restrictions. See INTERNATIONAL MONETARY FUND, 21sT ANNUAL REPORT ON EXchange REsTrictions (1970). With regard to these restrictions, however, most of which apply not only to the United States but rather to all countries, a finding of "undue burden" is even more difficult.

2121 U.S. Comm'n ON INTERnational Trade \& University Policy, supra note 211, at 695 (1971).

213 Thus, Pres. Proclamation No. 4074, 36 Fed. Reg. 15,724 (1971), is entitled "Imposition of Supplemental Duty for Balance of Payments Purposes."

214 The Act was passed primarily in order to authorize the President to enter into trade discussions with other countries and the EEC for mutual reduction of tariff rates. S.D. METzGER, supra note 192, at 17-18. These discussions became known as the "Kennedy Round." For a study of the history of the negotiations, an analysis of the results, and an evaluation of implications for future trade policy, see E. PreEg, Traders and Diplomats (1970). 
basis for the surcharge, although as will be indicated it does not seem to be the section on which the drafters of the Proclamation relied.

The three conditions under which the President may act are as follows:

(a) Whenever unjustifiable foreign import restrictions impair the value of tariff commitments made to the United States, or prevent the expansion of trade on a mutually advantageous basis ....

(b) Whenever a foreign country or instrumentality the products of which receive benefits of trade agreement concessions made by the United States-

(1) maintains nontariff trade restrictions, including variable import fees, which substantially burden United States commerce in a manner inconsistent with provisions of trade agreements, or

(2) engages in discriminatory or other acts (including tolerance of international cartels) or policies unjustifiably restricting United States commerce ....

(c) Whenever a foreign country or instrumentality, the products of which receive benefits of trade agreement concessions made by the United States, maintains unreasonable import restrictions which either directly or indirectly burden United States commerce ....

In considering the legislative history of this section, the same points should be noted that were mentioned respecting section 350 (a) of the Tariff Act-that Congress was more concerned with the power to lower rates than to raise them ${ }^{215}$ (this time in anticipation of the Kennedy Round) and that no consideration was given to a possible surcharge.

It is clear from the language and legislative history of the Act that section 252 was not meant to give the President a free hand. ${ }^{216}$ As

215 Indeed, nine volumes of hearings before the House Ways and Means Committee are filled with the fears of United States industries, often echoed by congressmen. See, e.g., Hearings on H.R. 9900 Before the House Comm. on Ways o Means, 87th Cong., 2d Sess., pt. 4, at 2348 (1962) (statement of Max Berkowitz, Director of the National Authority Ladies' Fandbag Industry).

216 The limitations were recognized by Congress, 108 Cong. REc. 19,867 (1962) (statement of Sen. Hubert $H$. Humphrey) and were acknowledged by the Administration, Hearings on H.R. 11970 Before the Senate Comm. on Finance, 87th Cong., 2d Sess., Pt. 4, at 2233 (1962) [hereinafter cited as 1962 Senate Hearings]. Under Secretary Ball stated that "under section 252 ... we have the power to return to the Smoot-Hawley tariff by the withdrawal of concessions in cases where they impose an illegal restriction." Id. Although opponents of the Act, such as Rep. Robert L. F. Sikes, claimed in debate that no restrictions were placed on presidential power and that the Act represented a "complete surrender of congressional authority," 108 CoNG. REc. 11,911 (1962), leaders of the op- 
was the case with section 350(a) of the Tariff Act, there were attempts to broaden the President's power beyond enabling him to respond to foreign restrictions. Thus, the first version of section 252 in the Administration bill would have allowed the President to withdraw concessions if other countries engaged in "policies which in his opinion tend to defeat [the promotion of foreign trade]."217 The House Ways and Means Committee scrapped this section entirely and inserted subsections (a) and (b) of present section 252; the Senate added subsection (c). ${ }^{218}$

The Senate also added a sweeping provision, section $353,{ }^{219}$ which provided:

Notwithstanding any other provision of law, the President may, when he finds it in the national interest, proclaim with respect to any article imported into the United States-

(1) the increase of any existing duty on such article to such rate as he finds necessary,

(2) the imposition of a duty on such article (if it is not otherwise subject to duty) at such rate as he finds necessary, and

(3) the imposition of such other import restrictions as he finds necessary.

This section would have authorized the present surcharge since it sanctioned any import restrictions that the President might find to be in the national interest. ${ }^{220}$ Section 353 , however, was subsequently deleted by the Conference Committee, ${ }^{221}$ creating a strong presumption

position, such as Sen. Carl T. Curtis of the Finance Committee, recognized that presidential power had been limited, 108 CoNG. REc. 12,000 (1962).

217 H.R. 9900, 87th Cong., 2d Sess. \& 242 (1962). It provided:

The President shall, when he determines that the purposes of this Act will be promoted thereby, suspend the reduction or elimination of any duty or other import restriction provided in any proclamation issued in carrying out any trade agreement under this title or any predecessor Act to products of any foreign country which engages in discriminatory treatment of United States commerce or engages in other acts, including the operations of international cartels, or policies which in his opinion tend to defeat such purposes.

218 H.R. REP. No. 1818, 87th Cong., 2d Sess. 42 (1962); S. REP. No. 2059, 87th Cong., 2d Sess. 2-3 (1962). Subsection (c) was an amendment to the House bill added in the Senate Finance Committee, apparently at the urging of Sen. Paul C. Douglas. Cf. 1962 Senate Hearings, supra note 216 , pt. 1 , at $168-69$.

219 H.R. 11970, 87th Cong., 2d Sess. (1962).

220 The broad "national interest" standard was emphasized in the Senate debate by Sen. Harry Byrd, Chairman of the Finance Committee. 108 Cong. REc. 19,570, 19,811 (1962). This point was also stressed by the proponent of the amendment, Sen. Herman $\mathrm{E}$. Talmadge. 108 CoNG. Rec. 19,811-12 (1962). Moreover, unlike section 252, section 353 would have allowed rates to be raised beyond the tariff levels of the Smoot-Hawley Act, 108 Cong. Rec. 19,810 (1962) (statement of Senator Douglas), and would have allowed quotas to be imposed, 108 Cong. Rec. 19;811 (1962) (statement of Senator Byrd).

221 H.R. REp. No. 2518, 87th Cong., 2d Sess. 13 (1962). It stated: "This amendment adds 
that Congress in passing section 252 wished to withhold such a power from the President..222

The three subsections of section 252 impose clear limits on the situations in which the President may act. Trade restrictions of foreign countries must either be "unjustifiable"223 or "substantially burden"224 United States trade.

It is clear that "unjustifiable" refers to restrictions which would be invalid under the GATT. As the Administration stated in opposing deletion of the "unjustifiable" requirement in the Senate Finance Committee,

These amendments would totally disregard the vital distinction between justifiable and unjustifiable import restrictions. Accordingly, they would require the President to take action against those import restrictions which are fully recognized and permitted by the General Agreement on Tariffs and Trade ... and thereby put us in violation of our international obligations. ${ }^{225}$

Many of the countries against which the surcharge was imposed were not in violation of the GATT. ${ }^{226}$ With respect to these countries, the presidential action was not authorized by the "unjustifiable" test of section 252.

a new section to the bill giving the President additional authority to increase tariffs, impose new tariffs on articles not otherwise subject to duty, and impose quotas when he finds it to be in the national interest. The Senate recedes."

222 The fact that these powers were eliminated does not weaken the conclusion that Congress also intended to eliminate the "national interest" standard because the Conference Committee could have deleted the quota and tariff-raising provisions while retaining the broad public interest test. Although the deletion was not explained, it is possible that the Administration had urged deletion because it feared that the EEC would perceive inclusion of such a measure as a threat which might occasion an unwillingness to engage in measures designed to liberalize trade. Cf. 1962 Senate Hearings, supra note 216, at 2204-06 (statement of Under Secretary Ball).

223 Section 252(a) requires "unjustifiable foreign import restrictions," section 252(b)(2) requires acts or policies "unjustifiably restricting United States commerce," and section 252(c) requires action by the President to have "due regard for the international obligations of the United States."

224 Section 252(a) requires that the restrictions "oppress the commerce of the United States," section 252(b)(1) requires that they "substantially burden" United States commerce, and section 252 (c) requires that they "either directly or indirectly substantially burden United States commerce."

2251962 Senate Hearings, supra note 216, at 1893. The Administration stated additional reasons for opposing deletion of the "unjustifiable" requirement: "In addition, they would encourage other countries to disregard the distinction between justifiable and unjustifiable import restrictions and permit them to justify retaliation against our import restrictions ... which are either permitted by the GATT or by waivers granted under the GATT." Id.

220 Most of the disregard for GATT rules seems to come from developed as opposed to less-developed countries. Cf. Hudec, supra note 55, at 1380-86. 
The "substantial burden" test raises the same obstacles to the surcharge as the "undue burden" test of section 350(a) and may impose a higher burden since it was aimed primarily at the effects that EEG restrictions could have on United States trade. 227 One other issue respecting this test does arise, however. Subsection (c) requires only that this burden be "indirect." Yet the legislative history shows that this requirement refers to the type of situation presented by EEG exclusion of Japanese textiles from its own market, which in turn would cause a greater influx into United States markets. 228 The effect of the exclusion, increased Japanese imports into the United States, would constitute the substantial burden and would allow the President to respond against the EEC. It should be obvious that very few countries could present the United States with such a burden.

c. Most-favored nation principle. Despite the apparent prohibition of a tariff increase on all countries without a finding of discrimination by each, the argument may be made that the most-favored nation principle requires such a uniform response. If the United States has legitimate cause to retaliate against EEC discrimination and therefore raises its rates on all articles traded by them, the contention would be that it must raise the rates on the same articles to all countries in order to act in a nondiscriminatory fashion. This argument is explicitly refuted, however, by the language and history of both the Tariff Act amendment ${ }^{229}$ and the Trade Expansion Act.

227 See 108 Cong. REc. 19,810 (1962) (statement of Senator Douglas, who proposed section 252(c)). See also id. at 19,859-60 (statement of Sen. Jacob K. Javits).

228 S. REP. No. 2059, 87th Cong., 2d Sess. 3 (1962); 108 CoNG. REc. 19,859-60 (statement of Senator Javits).

229 The most-favored nation provision of section 350(a) was repealed in 1962 by Trade Expansion Act of 1962, § 257(b), 76 Stat. 882 (1962), a technical amendment. Section 251 of the Trade Expansion Act, 19 U.S.C. \$ 1881 (1970), a new statement of the most-favored nation principle, was made applicable to trade agreements under the authority of both the Tariff and the Trade Expansion Acts. Before its repeal, section 350(a) provided:

The proclaimed duties and other import restrictions shall apply to articles the growth, produce, or manufacture of all foreign countries, whether imported directly, or indirectly: Provided, That the President may suspend the application to articles the growth, produce, or manufacture of any country because of its discriminatory treatment of American commerce or because of other acts or policies which in his opinion tend to defeat the purposes set forth in this section ....

Act of June 12, 1934, § 350(a)(2), ch. 474, 48 Stat. 943.

The only intelligible reading of this language shows a clear exception for the mostfavored nation principle where foreign import restrictions exist. This exception seems to work in two ways. First, if the United States negotiates lower rates, the new favorable rates need not be granted to discriminators. Second, and less clear from the language, if the President has once retaliated by raising rates on particular goods, all rates need not be raised. The ambiguity in the language arises because the amendment first provides that "import restrictions" apply to all articles and then states that this "application" does not apply in cases of discrimination. Were this taken literally, it would mean that if the 
Section 251 of the Trade Expansion Act, ${ }^{230}$ entitled "Most-Favored Nation Principle," provides:

Except as otherwise provided in this title,... any duty or other import restriction or duty free treatment proclaimed in carrying out any trade agreement under this title or section 350 of the Tariff Act of 1930 shall apply to products of all foreign countries, whether imported directly or indirectly.

The Senate Report states that " $[t]$ he references in the 'except clause' make clear, first, that import restrictions imposed under section . . . 252 of title II need not apply to products of all countries ..." (i.e., if all products of all countries do not meet the standards of section 252). ${ }^{231}$ This exception is required by the nature of section 252 , which allows a response only to discrimination. Compulsive most-favored nation tariff increases would violate the policy of selective retaliation.

d. Section 255: The case for unbridled discretion. Although the discrimination sections of the Tariff Act amendment and the Trade Expansion Act would seem to be most relevant in examining the authority for the surcharge, the apparent limitations on the President's power established by these provisions evidently led the Nixon Administration to seek still other justification. This is clear from the manner in which the Proclamation attempted to state the authority for the surcharge: "WHEREAS, under the Tariff Act, the TEA [Trade Expansion Act], and other provisions of law, the President may, at any time, modify or terminate, in whole or in part, any Proclamation made under his authority ...."232 This language is derived from section 350 (a) of the Tariff $\mathrm{Act}^{233}$ and a parallel provision of section 255 of

President raised a rate because of discrimination he would not have to apply the raised rates to discriminators-which would be contrary to the purpose of retaliation. Thus, the only alternative must be that once the rates are raised the most-favored nation principle does not apply, and consequently the rates of other nondiscriminators are not raised.

This interpretation is supported by the legislative history. Sen. Byron "Pat" Harrison, Chairman of the Finance Committee and the principal supporter of the bill, stated:

[T] he privileges granted to each nation are to be applied under the terms of the bill to all countries alike. To this general policy, however, the proposed legislation makes certain exceptions. The President may withdraw the enjoyment of such rates from any country because of its discriminatory treatment of American commerce . . . .

78 CONG. REC. 8988 (1934).

230 Trade Expansion Act of 1962, § 251, 76 Stat. 879 (codified in 19 U.S.C. § 1881 (1970)) (emphasis added).

231 S. REp. No. 2059, 87th Cong., 2d Sess. 16 (1962).

232 Pres. Proclamation No. 4074, para. 4, 36 Fed. Reg. 15,724 (1971).

23319 U.S.C. \& 1351(a)(6) (1970). It provides: "The President may at any time terminate, in whole or in part, any proclamation made pursuant to this section." 
the Trade Expansion Act. ${ }^{234}$ Section 255, entitled "Termination," provides:

(a) Every trade agreement entered into under this title shall be subject to termination or withdrawal, upon due notice, at the end of a period specified in the agreement. Such period shall be not more than 3 years from the date on which the agreement becomes effective. If the agreement is not terminated or withdrawn from at the end of the period so specified, it shall be subject to termination or withdrawal thereafter upon not more than 6 months' notice.

(b) The President may at any time terminate, in whole or in part, any proclamation made under this title.

The fundamental question, therefore, is whether the President may accomplish under section 255(b) what he may not under section 350(a) of the Tariff Act or section 252 of the Trade Expansion Act.

The Administration claimed that section 255(b) placed "no conditions or qualifications" on the President's authority. ${ }^{235}$ This claim

23419 U.S.C. § 1885 (1970). The codified version substitutes "under this subchapter" for "under this title."

235 NEP Hearings, supra note 125, at 23 (opinion of the General Counsel of the Treasury, entitled "Legal Basis for the Imposition of the Surcharge"). The opinion relies solely on this section for justification. Its full argument is as follows:

There are no conditions or qualifications placed on the President's termination authority under sections $350(a)(6)$ or $255(\mathrm{~b})$. There is no evidence in the legislative history either of the Tariff Act or of the TEA that the President's authority to terminate prior proclamations was to be any less broad than its language would suggest. On the contrary, the retention of the same unqualified language for almost forty years although there have been numerous amendments of the trade agreements authority indicates a Congressional intention to grant to the President broad discretionary power in this area. When originally enacted in 1934 as part of the Reciprocal Trade Agreements Act (48 Stat. 943), the termination authority formed the concluding sentence of subsection (a)(2) of section 350, and provided: "The President may at any time terminate any such proclamation in whole or in part." Although Congress frequently amended other provisions of section 350(a) of the Tariff Act, the termination authority remained unqualified. In 1962, when Congress passed the TEA, it repealed (section 257(b) of the TEA) portions of section 350(a), but retained the termination authority as part of the Tariff Act and added the same unqualified authority to terminate proclamations to the TEA.

In addition, the courts have generally given a broad construction to the President's termination powers and have refused to imply limitations on these powers. American Bitumuls and Asphalt Co. et al. v. United States, 44 CCPA 199 (1957, cert, den, 355 U.S. 883 (1957); United States v. Metropolitan Petroleum Corp., 42 CCPA 38 (1954); Baer v. United States, 8 Cust. Ct. 104 (1942); and Barclay and Company, Inc. v. United States, 41 Cust. Ct. 135, C.D. 2031 (1958), affirmed, 47 CCPA 133, C.A.O. 745 (1960).

Thus, the language of the statute, the legislative history and the broad interpretation given to the termination authority by the courts clearly show that the President had authority under section 350(a)(6) of the Tariff Act and 255(b) of the TEA to impose the import surcharge.

One can make the following points about this argument: (1) it totally ignores sections 350 (a) and 252, which speak directly to withdrawal of trade concessions; (2) the absence of amendment of these provisions is significant only if one assumes that Congress ever 
has the effect, however, of making the other substantive provisions, which do condition and qualify presidential power, mere surplusage. Such an interpretation violates the fundamental principle of statutory construction that all provisions of a statute must be construed together so as to preserve the meaning of each.

As will be demonstrated, section 255 (b) is not a substantive provision at all, but rather a technical and procedural one. This is first made clear by the use of the word "terminate" rather than the word "suspend," which is used in section 252. This choice is dictated because section 255 (b) speaks only to prior proclamations which are

suspected these provisions did confer unbridled discretion, which Congress never did; and (3) the cases relied upon constitute no authority for the position taken.

American Bitumuls \& Asphalt Co., Metropolitan Petroleum, and Barclay all involved the termination of a trade agreement with Mexico by Pres. Proclamation No. 2091, 64 Stat. A427; see T.D. 52,559, 85 Treas. Dec. 252 (1950). Since this termination was at the consent of both parties to the agreement, the authority to terminate was not at issue. Moreover, the import surcharge did not terminate a trade agreement but rather suspended a trade concession. The only real issue in the cited cases was whether the termination raised the tariff rate more than fifty percent in violation of section $350(a)(2)$, and the narrow holding was only that the fifty percent limitation does not apply when trade agreements are terminated.

The Baer case also involved the termination of a trade agreement. The agreement in question was with Czechoslovakia, applied to Yugoslavia through most-favored nation treatment, and was terminated in 1939 by President Roosevelt upon the German occupation of Czechoslovakia. The plaintiff importer argued that the termination was ultra vires in part under section $350(a)(2)(b)$. The court stated that it could not review presidential termination of a trade agreement because it is a political act, citing Terlinden v. Ames, 184 U.S. 270 (1902), and that it could review only modification of a trade agreementwhich is the case with the surcharge. The Terlinden citation is completely inapposite. It held merely that habeas corpus could not be used to question the validity of an extradition treaty on the ground that it had terminated when the foreign signatory state was consolidated into the German Empire, since that determination was consigned exclusively to the President. Termination of all trade agreements since 1930 would, of course, result in the loss of all tariff concessions given to the United States by all countries during that time. Moreover, under the Trade Expansion Act the authority to terminate trade agreements is contained in section $255(\mathrm{a})$, not section $255(\mathrm{~b})$.

The contention that under section 350 (a) the President may at any time modify a previous proclamation in order to raise a duty above the level recommended by the Tariff Commission was rejected in United States v. Schmidt Pritchard \& Co., 47 C.C.P.A. 152, cert. denied, 364 U.S. 919 (1960). The only substantive authority relied on by the President, section 7 of the Trade Agreements Extension Act of 1951, was not available as construed, and consequently the proclamation in that case was held invalid as exceeding the authority delegated to the President: "The power to terminate his own proclamation can grant no greater discretion to the President than that under which adjustments are proclaimed." Id. at 160. Likewise, in Falcon Sales Co. v. United States, 199 F. Supp. 97 (Cust. Ct. 1961), the argument that a proclamation purporting to suspend in part earlier proclamations may be read as terminating them in part was rejected, and the limitation on presidential power set forth in Schmidt Pritchard was held applicable to an attempted. suspension. 
terminated, not to the conditions under which tariff rates or trade agreements are suspended. When a trade agreement concession is withdrawn, the trade agreement is not terminated; rather, particular provisions of that agreement are suspended. It is only the prior proclamation, the function of which is to announce and publish concessions, ${ }^{236}$ which is terminated. Thus, the surcharge was viewed as only "temporary," and the Administration did not claim that every trade agreement negotiated since 1934 had been terminated. If this view is accepted, section 255 (b) may be reconciled with section 252 . The latter sets down the conditions under which the President may suspend trade concessions, while the former enables the President to terminate the prior proclamation which had made the concession rate effective.

An inadvertent recognition of this difference is revealed by the reference in the Proclamation to the authority of the President to "modify or terminate, in whole or in part, any Proclamation made under his authority." The inclusion of the word "modify," which is absent entirely from section $255(\mathrm{~b})$, inaccurately attempts to bolster the claim that section 255(b) is concerned with the power to "suspend" trade concessions. ${ }^{237}$ The drafters of the Proclamation appear to have been forced into this formulation because section $255(\mathrm{~b})$ as written would not support the action taken. ${ }^{238}$

230 This seems to be the only function of the proclamation. See 1934 House Hearings, supra note 203, at 360 (statement of Assistant Secretary Sayre).

237 Modification of proclamations by additional proclamations is common. See, e.g., Pres. Proclamation No. 3967, 3 C.F.R. \$§ 28, 30 (1970). In each case, however, the power to modify is derived from substantive sections of the relevant legislation. Thus, Pres. Proclamation No. 3967, supra, drew on the authority of sections 201(a)(2), 203(a)(2)-(3), and 351(a)(1) of the Trade Expansion Act. On the other hand, the surcharge proclamation, Pres. Proclamation No. 4074, 36 Fed. Reg. 15,724 (1971), purports to see the modification "power" as residing in section $255(\mathrm{~b})$, which is not a substantive provision.

238 The view that independent powers are contained in section 255(b) seems explained in part by accidents of codification which separated the "termination" section from the substantive sections of the Act. This may be clarified by an examination of statutory antecedents.

The heritage of section $255(\mathrm{~b})$ can be traced to section 338 of the original Tariff Act, 19 U.S.C. \& 1338 (1970), which enables the President to impose additional duties against foreign discriminators. Section 338 allows the President under various conditions precedent to raise tariff rates by proclamation. Subsection (c), entitled "Application of Proclamation," then provides: "Any proclamation issued by the President under the authority of this section shall, if he deems it consistent with the interests of the United States, extend to the whole of any foreign country . . . and the President shall, whenever he deems the public interests require, suspend, revoke, supplement, or amend any such proclamation." It is clear from both the language and the placement of this provision that it establishes no new substantive power to raise rates. It authorizes the President only to modify a prior proclamation which had raised rates.

Additional proclamation language appeared when section $350(a)$ of the Act was amended in 1934. Act of June 12, 1934, ch. 474, $\S 350(a)(2), 48$ Stat. 944. The amendment provision 
What section 255(b) is actually concerned with is the need to avoid two inconsistent proclamations. The potential for inconsistency arises in two situations. First, a trade agreement may be negotiated and a proclamation issued to give notice of the new tariff rates. If at some later time the President finds that foreign restrictions are unduly burdening United States trade and withdraws certain concessions granted in the trade agreement, he must issue another proclamation to provide notice of the change. In so doing he must terminate "in part" the prior proclamation which had announced the trade agreement rates. Second, if at some still later time the President seeks to reinstate the trade agreement rate, he must issue a third proclamation terminating "in whole" the second proclamation which had withdrawn the concessions. ${ }^{239}$

followed directly after the language limiting the power of the President to raise or lower rates and to create exceptions to the most-favored nation principle. It provided that "the proclaimed duties and other import restrictions shall be in effect from and after such time as is specified in the proclamation. The President may at any time terminate any such proclamation in whole or in part." (Emphasis added.)

In 1962 the provisions of the 1934 amendment which stated the exception to the mostfavored nation principle were replaced by the new languge of section 251 of the Trade Expansion Act. This necessitated the repeal of the language of section 350(a)(2) of the Tariff Act, ". . . the proclaimed duties and other import restrictions shall be in effect from and after such time as is specified in the proclamation," which was accomplished by section 257(b) of the Trade Expansion Act. The termination clause was left stranded and unintelligible because it referred to "any such proclamation"-the one raising rates which had been repealed. The codifiers then changed the language to read, "The President may at any time terminate, in whole or in part, any proclamation made pursuant to this section." (Emphasis added.) This formulation was intended not to make any substantive change but rather only to clarify that when rates are raised by proclamation the prior trade agreement proclamation must be terminated in part. The only reason for believing that the section confers independent power is a highly superficial one-its printed distance from the substantive provisions controlling the President's discretion.

239 For an example of a series of proclamations, see those affecting sheet glass. Pres. Proclamation No. 3140, 3 C.F.R. \$ 74 (1956) (modifying existing duties where required or appropriate to carry out United States trade agreements, by authority of section 350 of the Tariff Act); Pres. Proclamation No. 3455, \& C.F.R. § 166 (1962) (increasing rates, by authority of section 350(a) of the Tariff Act and section 7 (c) of the Trade Agreements Extension Act of 1951); Pres. Proclamation No. 3458, 3 G.F.R. § 171 (1962) (modifying Pres. Proclamation No. 3455 by postponing its effective date, by authority of the sections cited in No. 3455 itself); Pres. Proclamation No. 3548, 3 G.F.R. § 298 (1963) (establishing schedules, by authority of section 102 of the Tariff Classification Act of 1962); Pres. Proclamation No. 3762, 3 C.F.R. \& 20 (1967) (terminating Pres. Proclamation No. 3455 and Pres. Proclamation No. 3458 to the extent that it modified No. 3455 and decreasing the increased rate effected by No. 3455 , by authority of section $351(\mathrm{c})(1)(\mathrm{A})$ of the Trade Expansion Act); Pres. Proclamation No. 3816, 3 C.F.R. \& 90 (1967) (extending the remaining increased duties, by authority of section 351(c)(2) of the Trade Expansion Act); Pres. Proclamation No. 3951, 3 C.F.R. $\$ 86$ (1969) (further extending the remaining increased duties, by authority of section 351(c)(2) of the Trade Expansion Act); and Pres. Procla- 
The legislative history contains almost no direct discussion of either section $255(\mathrm{~b})$ or the parallel provision of section 350(a) of the Tariff Act. ${ }^{240}$ However, no person in the Administration or Congress has ever suggested that this provision confers any substantive power on the President. In fact, when Sen. Eugene McCarthy of the Finance Committee ${ }^{241}$ compiled an inventory of powers given to the President in the Trade Expansion Act "to safeguard genuine competition," section 255 (b) was not among them. ${ }^{242}$ The position that a provision conferring extensive power on the President would go undiscussed by two Congresses carefully jealous of the surrender of legislative power is untenable.

3. Executive Afterthoughts. The Proclamation did not rest solely on statutory authority; it attempted to create additional justification by announcing a national emergency. The Proclamation stresses the "crisis" in its title, "Imposition of Supplemental Duty for Balance of

mation No. 3967, 3 G.F.R. $\$ 28$ (1970) (extending and modifying the rates, by authority of sections 201(a)(2), 302(a)(2)-(3), and 351(a)(1) of the Trade Expansion Act).

In each of the proclamations affecting sheet glass duties, it should be noted, specific substantive authority for the action being taken was cited. This is also true of all other proclamations affecting duties prior to the proclamation of the surcharge, which relies only generally on statutory authority "including, but not limited to, the Tariff Act of 1930, and the Trade Expansion Act of 1962 ... . Pres. Proclamation No. 4074, 36 Fed. Reg. 15,724 (1971). An additional step in the failure to premise presidential action on specific substantive authority is suggested in the recent proclamation establishing a ceiling on stainless steel fiatware. Pres. Proclamation No. 4076, 36 Fed. Reg. 16,561 (1971). There authority is claimed under section 350(a)(1)(B) of the Tariff Act, section 201(a)(2) of the Trade Expansion Act, "and, as separate and additional authority," sections 350(a)(6) and 255(b) of those Acts, respectively (the termination provisions).

240 One of the few exceptions occurred in 1962 with respect to section 244(b) of the Administration bill, H.R. 9900, 87th Cong., 2d Sess. (1962), which was in relevant part identical to the present section $255(\mathrm{~b})$. The context was an exchange of views between Under Secretary Ball and Rep. Jackson E. Betts during hearings before the Ways and Means Committee. Representative Betts asked, "To make sure I understand the mechanics, the agreement entered into, then that agreement is not effective until the proclamation. The proclamation follows the provisions of the agreement?" Undersecretary Ball answered, "And of the Act." Betts continued, "And it will not in any case include an increase in tariffs but after it has been in effect over a period of time and the President finds there should be an increase, then under 244(b), he has the right, regardless of what the provisions of the trade agreement are-," to which Ball replied, "He has the right, but he is subject to the requirements of GATT which means that he must come in and discuss the possibilities of compensation under GATT." 1962 House Hearings, supra note 200, pt. 6, at 3871 (emphasis added). This exchange may be read as seeing in section 244(b) the "right" of the President to increase tariffs, but as Representative Betts noted this right is operative only after the President "finds there should be an increase"-a finding which must be made pursuant to the limitations of section 252. Id.

241 Congressional Directory, 87th Cong., 2d Sess. 235 (1962).

242108 ConG. REc. 19,872 (1962). A similar omission occurred when Commerce Sec. Luther Hodges made a compilation for the Senate Finance Committee, 1962 Senate Hearings, supra note 216 , at 2280 . 
Payments Purposes," and begins with a recitaton of the "crisis": "WHEREAS, there has been a prolonged decline in the international monetary reserves of the United States, and our trade and international competitive position is seriously threatened and, as a result, our continued ability to assure our security could be impaired . . ."243 The President later proclaims, "I hereby declare a national emergency during which I call upon the public and private sector to make the efforts necessary to strengthen the international economic position of the United States."'244

a. Trading with the Enemy Act. No clarification of the possible significance of this declaration was made by the President at the time the surcharge was imposed. It later appeared, however, that the "national emergency" was intended to activate the authority that the President possesses under section 5(b) of the Trading with the Enemy Act, ${ }^{245}$ which in turn was intended to justify the surcharge. ${ }^{246}$ Section 5(b) grants broad authority to the President, during war or presidentially declared national emergency, to regulate trade and financial transactions between Americans and foreign persons. Under this authority, the President may "regulate ... importation or exportation of ... any property in which any foreign country or a national thereof has any interest." 247

In deciding whether the above framework may be used as authority for the surcharge, two questions must be answered: (1) did the President have the power to declare a "national emergency"? and, if so, (2) does the Trading with the Enemy Act allow the imposition of the surcharge?

243 Pres. Proclamation No. 4074, para. 1, 36 Fed. Reg. 15,724 (1971).

244 Id. para. 6, 36 Fed. Reg. 15,724.

24512 U.S.C. § 95(a) (1970). This section of the comment relies heavily on the thorough study of Garson \& Miller, The Foreign Direct Investment Regulations: Constitutional Questions and Operational Effects Examined, 11 B.C. IND. \& CoM. L. REv. 143 (1970).

246 See Senate Comim. on Finance, The Revenue Act of 1971, S. Rep. No. 92-487, 92d Cong., Ist Sess. 136 (1971); Wall Street Journal, Nov. 5, 1971, at 4, col. 2 (Midwest ed.).

247 Section $5(\mathrm{~b})$ reads in part:

(1) During the time of war or during any other period of national emergency declared by the President, the President may, through any agency that he may designate, or otherwise, and under such rules and regulations as he may prescribe, by means of instructions, licenses, or otherwise-

(A) investigate, regulate, or prohibit any transactions in foreign exchange, trans. fers of credit or payments between, by, through, or to any banking institution, and the importing, exporting, hoarding, melting, or earmarking of gold or silver coin or bullion, currency, or securities, and

(B) investigate, regulate, direct and compel, nullify, void, prevent or prohibit, any acquisition, holding, withholding, use, transfer, withdrawal, transportation, importation or exportation of, or dealing in, or exercising any right, power, or privilege with respect to, or transactions involving any property in which any foreign country or a national thereof has any interest. 
i. National emergency. Although the power of the President to declare national emergencies in time of war pursuant to his constitutional designation as Commander-in-Chief ${ }^{248}$ seems well-established, ${ }^{249}$ the constitutional status of emergencies declared in order to regulate the peacetime economy is open to question. Prior to the Nixon Administration's balance-of-payments emergency, the only such economic emergency ever declared was that proclaimed by President Roosevelt in the heart of the Depression to announce a bank holiday. ${ }^{250}$ Since at that time section $5(\mathrm{~b})$ powers were restricted to wartime situations, the Administration rushed an amendment through Congress so that the section could be activated by the national emergency declaration. ${ }^{251}$

The Depression emergency was never challenged directly, probably because the subsequent amendment of section $5(b)$ sufficed as a congressional delegation of power even though the President did not possess the power originally. ${ }^{252}$ The cases that do focus on the national emergency power have dealt only with the types of regulation section 5 (b) can support once an emergency is declared-i.e., have assumed the emergency to be valid. Moreover, with one exception, they treat only the legitimacy of economic regulation under wartime emergencies or economic regulation in situations in which war is imminent. ${ }^{253}$

The question of the import surcharge, an economic emergency measure for peacetime economic regulation, has been dealt with only in-

248 U.S. Const. art. II, § 2.

249 Martin v. Mott, 25 U.S. (12 Wheat.) 19 (1827) initiates the line of cases. President Truman declared a national emergency during the Korean War in Pres. Proclamation No. 2914, 3 C.F.R. $\S 99$ (Comp. 1953), 50 U.S.C. App. notes preceding $\S$ I (1970). It provides:

[R]ecent events in Korea and elsewhere constitute a grave threat to the peace of the world and imperil the efforts of this country and those of the United Nations to prevent aggression and armed conflict .... [W World conquest by communist imperialism is the goal of the forces of aggression that have been loosed upon the world . . . [T] he increasing menace of the forces of communist aggression requires that the national defense of the United States be strengthened as speedily as possible . . . .

The Korean emergency has been legitimized in Sardino v. Federal Reserve Bank, 361 F.2d 106 (2d Cir.) (Friendly, J.), cert. denied, 385 U.S. 898 (1966), and in Nielsen v. Secretary of the Treasury, 424 F.2d 833 (D.C. Cir. 1970) (Leventhal, J.).

250 Pres. Proclamation No. 2039, 31 C.F.R. § 120.1 (1933).

251 Garson \& Miller, supra note 245, at 148-50 \& n.35.

252 Id. at 148. See United States v. Biddle, 212 F. Supp. 584 (S.D. Cal. 1962), overruled, Pike v. United States, 340 F.2d 487 (9th Cir. 1965). In Biddle the court stated in dictum, "Although this action [declaring the bank holiday] was cheerfully accepted, and even welcomed, at the time, it was clearly unauthorized, since nowhere in the Constitution is the President given authority to act in an "emergency" as such, and the requisite war conditions which might have called into play his granted power as Commander-in-Chief or his delegated power under the Trading With The Enemy Act of 1917 did not obtain." 212 F. Supp. at 586.

253 The exception is Pike v. United States, 340 F.2d 487 (9th Cir. 1965). See note 260 infra. 
directly in a few Ninth Circuit cases, in which the issue was whether peacetime economic regulation could stand on the authority of the Depression emergency once the Depression had long passed. The Ninth Circuit was asked in 1957 in Bauer $v$. United States ${ }^{254}$ to overturn a conviction for the possession of gold bullion in violation of the Gold Hoarding Regulations ${ }^{255}$ issued under the authority of section $5(\mathrm{~b})$. The Regulations were challenged on the ground that the Depression emergency no longer existed. Determination of this question logically involves analysis of whether Congress, in using the term "emergency" in section $5(\mathrm{~b})$, meant to include a peacetime situation less drastic than the Depression. ${ }^{256}$ If not, the use of the Depression emergency in the economic calm of the late 1950s would exceed the scope of delegated power. The only other alternative would be to find that the power to regulate the economy is the President's under the Constitution and consequently does not require congressional delegation. This might be done by linking up national emergencies with a loose definition of the foreign affairs power, ${ }^{257}$ which is itself a loose definition of the commander-in-chief clause. ${ }^{258}$ The Bauer court, however, merely recognized the danger of vast economic regulatory power concentrated in the President and remanded the case for a determination of the continued existence of the Depression emergency. A later Ninth Circuit case, Pike v. United States, ${ }^{259}$ also avoided the crucial questions

254244 F.2d 794 (9th Cir. 1957).

255 Exec. Order No. 6260,12 U.S.C. $\$ 95 a$ note (1970). This order, promulgated in conjunction with the 1933 bank holiday, has been carried forward by Presidents Eisenhower and Kennedy by authority of the Korean emergency. Exec. Order No. 10,896, 3 C.F.R. $\S 425$ (Comp. 1963); Exec. Order No. 10,905, 3 C.F.R. \& 436 (Comp. 1963); Exec. Order No. 11,037, 3 C.F.R. \& 621 (Comp. 1963).

250 The legislative history indicates that they did not so intend. Garson \& Miller, supra note 245 , at 149 n.35.

257 Presidential power in the conduct of foreign relations is not, of course, dependent on congressional delegation but rather derives from the Constitution. United States v. Curtiss-Wright Export Corp., 299 U.S. 304 (1936). His power over foreign commerce, however, is not inherent and requires delegation. Chicago \& Southern Air Lines v. Waterman S.S. Corp., 333 U.S. 103 (1948). Whether a given exercise of power affecting foreign affairs is inherent or requires delegation is not always clear. United States v. Shaughnessy, 338 U.S. 537 (1950), held that presidential power to exclude aliens is of the former origin. The argument that the power to impose duties is within the President's inherent foreign relations power cannot be made so easily, however, for at some point little is left of congressional power. The fact that Congress has delegated some of its power increases the area in which no inquiry as to origin need be made but makes inquiry more difficult in the absence of delegation. See generally Bassiouni \& Landau, Presidential Discretion in Foreign Trade and its Effect on East-West Trade, 14 WAYNE L. REv. 494, 495-505 (1968); Fisher, Delegating Power to the President, 19 J. PUв. L. 251 (1970).

258 U.S. CoNST. art. II, \& 2.

259340 F.2d 487 (9th Cir. 1965). 
by deciding that the Gold Hoarding Regulations could be justified under the Korean War emergency declared by President Truman while noting that the Government conceded that the Depression emergency no longer existed.

Although $P i k e$ and other cases $^{200}$ suggest that peacetime economic regulation based on the Korean emergency may succeed even if the Depression emergency is not extended, the Nixon Administration did not attempt to justify the surcharge on this basis but instead declared a new national emergency. Perhaps this is explained by a reticence to stretch the purported scope of the Korean emergency too far. ${ }^{261}$ The consequence, however, is that the Korean precedents can bear only indirectly on the newly declared emergency.

As a question of policy, it seems that Congress should not be viewed, by its inclusion of emergency authority in Section $5(\mathrm{~b})$, as authorizing the President to engage in total regulation of the economy by mere incantation of the word "emergency." A better view is that the term encompasses only severe domestic crises such as the Depression. In less drastic situations the President should be required to go to Congress for regulatory authority. As Professor Corwin points out, presidential use of emergency power is justified in situations "which have not attained enough of stability or recurrency to admit of their being dealt with according to rule." 262 This may have been the case in the heart

260 Nielsen v. Secretary of the Treasury, 424 F.2d 833 (D.C. Cir. 1970) (Leventhal, J.), and Sardino v. Federal Reserve Bank, 361 F.2d 106 (2d Cir.) (Friendly, J.), cert. denied, 385 U.S. 898 (1966), both upheld the Cuban Assets Control Regulations on the authority of the Korean emergency. Both courts felt required, however, to mention that the Cuban situation was connected to the communist threat underlying the Korean emergency. 424 F.2d at 839; 361 F.2d at 109. If these cases imply a defense-related scope for regulations resting on the authority of the Korean emergency, they may explain the Nixon Admin. istration's refusal to use that emergency as support for the surcharge. If Pike goes further, by stating that the Trading with the Enemy Act may support any proclamation or regulation whether during peace or war-with the consequence that the surcharge could stand on the authority of its own declared emergency, or perhaps the Korean emergency-then it should not be followed. Rather, it should be limited to its facts. The Gold Hoarding Regulations in Pike had been issued in 1933, and the court was naturally reluctant to overturn regulations which had been in effect for more than thirty years. The surcharge, on the other hand, involves an extension as opposed to a continuance of regulations. No court has yet approved such an extension in peacetime and in the absence of a serious emergency.

261 Garson \& Miller, supra note 245, at 159. There is old authority that review of the scope of an emergency is proper. Chastleton Corp. v. Sinclair, 264 U.S. 543 (1924) (Holmes, J.). Of course, the loose language of the surcharge proclamation would not preclude ultimate reliance on the Korean emergency.

262 E. Corwin, The President 3 (4th ed. 1957). As Professor Corwin points out, the Presidency is the branch of government most responsive to emergency conditions, which he defines as those situations which do not recur. 
of the Depression, but it is not so when the United States balance of payments is in deficit, a situation which has existed in every year but two since $1950 .{ }^{263}$ More important, the President's ability to declare national emergencies and to acquire broad power must be limited if we are to avoid the concentration of executive power feared by the framers of the Constitution. ${ }^{264}$ If the courts are unwilling to review these decisions and Congress takes no active steps to reverse the trend, ${ }^{265}$ each must bear responsibility for the results.

ii. Imposition of the surcharge. The second question posed by the national emergency rationale is whether, assuming the emergency is valid, the Trading with the Enemy Act allows the imposition of the surcharge.

The surcharge, while it might be supported by the broad power to regulate importation and exportation of the property of foreign nationals and countries, is the only tariff measure ever used under the Act. While the section has successfully supported foreign assets control regulations ${ }^{288}$ prohibiting unlicensed commercial transactions of any kind with such countries as China, North Korea, North Vietnam, ${ }^{267}$ and Cuba; ${ }^{288}$ trade embargoes against belligerents; ${ }^{269}$ and the Gold Hoarding Regulations, ${ }^{270}$ it has never been used, with court approval, against all countries in the fashion of the surcharge.

The closest approximation to such use is the Foreign Direct Investment Regulations ${ }^{271}$ (FDIRs), issued by President Johnson in 1968, which restrict the amounts of capital that American investors may transfer to or accumulate in foreign affiliates and compel repatriation of short-term liquid balances such as foreign bank deposits. Their validity has yet to be tested in the courts. ${ }^{272}$ Like the surcharge, they constitute a peacetime regulation of foreign economic commerce addressed to the balance-of-payments problem. Unlike the surcharge, they are justified under the Korean emergency and involve an area void of other legislation such as the Tariff and Trade Expansion Acts. The

263 Senate Comm. on Finance, supra note 246, at 134 (on a liquidity basis).

264 The Federalist Nos. 48-49 (J. Madison).

285 See Kurland, The Reticence of Impotence, 1968 DurE L.J. 619.

206 Nielsen v. Secretary of the Treasury, 424 F.2d 833 (D.C. Cir. 1970) (Leventhal, J.).

20731 C.F.R. \& 500.201 (1971).

26831 C.F.R. § 515.201 (1971).

269 Egyptian Assets Control Regulations, 21 Fed. Reg. 5777 (1956), as amended, 21 Fed.

Reg. 5861-62 (1956) (repealed 1958) (response to Suez crisis).

27012 U.S.C. § 95a note (1970); see Pike v. United States, 840 F.2d 487 (9th Cir. 1965).

271 15 C.FR. §§ 1000.101-.1405 (1971), 12 U.S.C. § 95a note (1970).

272 Cf. 42 Or, ATT'Y GEN. 35 (1968) (Ramsey Clark to Commerce Sec. C.R. Smith). 
latter difference is critical in interpreting the scope of power authorized in section $5(\mathrm{~b})$.

The main argument against legitimating the surcharge under section $5(b)$ is that it would render meaningless the limits placed on presidential discretion under the Tariff and Trade Expansion Acts. This argument should prevail even if it is contended that the Acts operate in normal times while the Trading with the Enemy Act operates in emergencies.

This view follows from two considerations. First, the Tariff and Trade Expansion Acts were not passed in times more significantly normal than that covered by the surcharge. In fact, the Tariff Act amendment was passed in the heart of the Depression. ${ }^{273}$ The same administration which declared the bank holiday still thought it necessary to come to Congress when it needed authority to act in the tariff field. Similarly, the Trade Expansion Act was a response to trade and balanceof-payments difficulties, as is clear in President Kennedy's message requesting the legislation. ${ }^{274}$

Second, Congress authorized the President in both Acts to respond to so-called emergencies by selectively retaliating against those who substantially burdened United States trade. This consideration cannot be dismissed by a claim that the acts are addressed to import restrictions whereas the surcharge goes to the balance-of-payments problem. As recognized by President Kennedy, the two are integrally related since foreign import restrictions both decrease exports and lead to a trade imbalance. ${ }^{275}$ Retaliation against such restrictions is one means of redressing that imbalance. Thus, Congress has spoken on the question of the trade segment of the balance-of-payments problem but not the capital flow segment, to which the FDIRs are addressed. Within this context, one may view the President's declaration of a national emergency as dissatisfaction with the policy embedded in the Tariff and Trade Expansion Acts and an attempt to pursue new policies despite the legislative judgment of past Congresses.

A final argument against legitimizing the surcharge under section $5(b)$ is that it is anomalous to include allies within the scope of the Trading with the Enemy Act. Although the property of nations not at war with the United States, as in the case of Cuba and Egypt, has

273 The Administration viewed the bill as an emergency provision. 1934 House Hearings, supra note 203 , at 5-6 (statement of Secretary Hull). See also id. at 79-80 (statement of Representative McCormack).

274 H.R. Doc. 314, 87th Cong., 2d Sess. 2 (1962). There were, of course, other enumerated reasons for the legislation as well.

275 Id. at 4. 
been regulated under the Act, ${ }^{278}$ it is a big step to "regulate" the property of all countries, including Latin America and NATO allies. Even South Vietnamese imports were subject to the surcharge. ${ }^{277}$ Again, this is unlike the FDIRs, which essentially regulate only American property to reduce capital outflows.

b. Revenue Act of 1971. The Nixon Administration evidently recognized the scarcity of authority for the surcharge under both the Tariff and Trade Expansion Acts and the Trading with the Enemy Act. Indeed, it "acquiesced" to proposed new legislation. ${ }^{278}$

The problem in obtaining new legislation was the political cost of admitting that the surcharge was an unauthorized action. This problem

270 Cuban Assets Control Regulations, 31 C.F.R. \$§ 515.101-.809 (Supp. 1969); Egyptian Assets Control Regulations, 21 Fed. Reg. 5777 (1956), as amended, 21 Fed. Reg. 5861 (1956) (repealed 1958) (response to Suez crisis).

277 Thus, Senate Finance Committee sources have reportedly stated that it would "obviously be an unseemly thing to apply to friendly countries." Wall Street Journal, Nov. 5, 1971, at 4, col. 2 (Midwest ed.). According to the Senate Report, "The Committee felt that the President should not have to resort to the 'Trading with the Enemy Act' when dealing with the balance of payments emergency, particularly with respect to our friendly trading partners." SENATE CoMm. ON FINANCE, supra note 246, at 136.

278 H.R. 10947, 92d Cong., Ist Sess. $\$ \S 601-05$ (1971). It is not clear that it was at the Administration's request that this legislation was introduced. New authority to impose tariff quotas and to raise certain statutory rates had been suggested by Senator Fanin as protection for industry, particularly automobile companies. NEP Hearings, supra note 125 , at 35-36. See also Hearings on H.R. 10947 Before the Senate Comm. on Finance, 92d Cong., 1st Sess. 122-23 (1971) (testimony of Arthur E. Summerfield, Sr., Chairman of the Board, Summerfield Chevrolet Co.) [hereinafter cited as 1971 Senate Hearings]. There is some indication, moreover, that certain senators would not have been content with amendment of the statutory rates on particular items such as automobiles because interests in their own states might feel left out. There was, therefore, some pressure of a protectionist variety for an across-the-board increase. See id. at 581 (statement of Sen. Russell Long, Chairman of the Finance Committee).

The Administration's public position toward the new legislation took some curious turns. When Secretary Connally testified before the Senate subcommittee reviewing the President's initiatives in October, he stated, "I would hope the President could have more authority in this field." NEP Hearings, supra note 125, at 113. After "additional" authority was granted by way of an amendment to the Revenue Act of 1971 inserted in the executive session of the Senate Finance Committee, Press Sec. Ronald Ziegler stated that "[t]he President did not request this authority and would not expect to use such powers." N.Y. Times, Nov. 10, 1971 at 67, col. 4 (city ed.). See also 117 Cong. Rec. S18,735 (daily ed. Nov. 16, 1971). After such opponents of "additional" authority as Senator Javits pressed for rejection of the amendment since it was not desired by the Administration, however, Asst. Treasury Sec. John S. Nolan sent Senator Long a letter stating that there were no possible adverse consequences of granting such authority and that "[u]nder these conditions, the Administration does not seek their elimination from the bill." 117 CoNG. REc. S18,747 (daily ed. Nov. 16, 1971). This letter was used by proponents of "additional" authority during the Senate debate on the measure. Id. at S18,741. The Administration's reluctance to appear to be asking for authority which it already claimed to have and its consequent posture of acquiescence are consistent with the conclusion that authority to impose the surcharge was originally lacking. 
was sidestepped by assigning the need to two other reasons: unwillingness to be forced to rely on the Trading with the Enemy Act and limitations on the freedom to adopt new measures beyond the ten percent surcharge under the Tariff and Trade Expansion Acts.

These reasons are not particularly persuasive. First, both assume that authority for the surcharge existed-an assumption which the Administration successfully persuaded the Ninety-second Congress to share without serious questioning despite its tenuous validity. Second, there was no need to apply the Trading with the Enemy Act to other countries insofar as the Administration claimed adequate authority under the Tariff and Trade Expansion Acts. ${ }^{279}$ Third, certain limitations on presidential action asserted to exist under the latter Acts are nonexistent. The claim that new authority was needed to terminate the increased tariffs "selectively with respect to individual articles, groups of articles or countries" is belied by the fact that under these Acts the President can reinstate trade agreement concessions at any time. ${ }^{280}$

Two claimed limitations of the Tariff and Trade Expansion Acts were legitimate: the inability to raise rates beyond the statutory limits set by Congress ${ }^{281}$ and the inability to impose quotas. ${ }^{282}$ However, the first problem, which is potentially serious in regard to only a few items of trade, could be solved by an amendment of statutory rates. The

279 Moreover, as Senator Javits pointed out quite forcefully during the Senate debate, the Trading with the Enemy Act had been applied to United States allies on a daily basis since 1969 under the FDIRs. 117 CoNG. Rec. S18,745 (daily ed. Nov. 16, 1971); see text at note 241 supra.

280 In fact, the Administration argued that section 201 of the Trade Expansion Act gave it this power. See NEP Hearings, supra note 125, at 24. Pres. Proclamation No. 4074, 36 Fed. Reg. 15,724 (1971), also assumes this authority in its delegation of power to the Secretary of the Treasury. See also H.R. REP. No. 1818, 87th Cong., 2d Sess. 14 (1962).

281 The statutory rates appear in column two of Tariff Schedules of the United States, 19 U.S.C. § 1202 (1970). (In some cases the column two rate may reflect previous tariff increases. See 19 U.S.C. App. $\$ 1202$ (1970).) Increases may not exceed fifty percent of the statutory rates existing on July 1, 1934. 19 U.S.C. $\S 1822$ (1970). The selection of this date, about one month after enactment of the Tariff Act amendment, insured that the statutory rates would be substantially those of the Tariff Act since no trade concessions could yet have been made under the newly passed amendment.

If the President had retaliated selectively, pursuant to section 252 of the Trade Expansion Act, he could have imposed a fifty percent surcharge where there had been no prior increases. It was only because he sought to operate under section $255(b)$ that the statutory rate limited the increase because all trade concessions which were withdrawn had originated with the rate established by statute. Even under section 255(b), moreover, there was no magic in the ten percent figure. If trade concessions had been more than ten percent, they too could have been withdrawn under the logic of that provision. New authority to go to fifteen percent was necessary only to operate under section 255(b), which was improper, and if prior trade concessions had been less than fifteen percent.

282 This power was given by section 353 of the Trade Expansion Act, deleted by the Conference Committee, See text and notes at notes 219-22 supra. 
second would require a simple amendment to section 252. Yet the Administration's request was not so limited.

The Nixon Administration in effect followed the Roosevelt strategy of 1933: declare a national emergency, take the desired policy action, and then go to Congress for the necessary legislation. This strategy had the advantage of solving the retroactivity problem if the new legislation were keyed to the existence of a national emergency-which it was. The only differences between 1971 and 1933 are that the bank holiday was an extreme crisis whereas the balance-of-payments problem had existed for several years and that President Roosevelt went openly and immediately to Congress for authority whereas the Nixon Administration waited almost three months, acted in the interim without statutory authority, and claimed while seeking authority that it was unnecessary.

The resulting proposed legislation was an amendment to the Revenue Act of 1971,283 introduced in the executive session of the Senate Finance Committee after hearings on the Act had been concluded. ${ }^{284}$ As reported to the Senate, the amendment contained four principal features: (1) the substantive powers contained in the legislation were automatically in force during a "balance-of-payments emergency period," which included the period of the national emergency proclaimed by the President for the imposition of the surcharge and any new periods which he might proclaim until 1976;285 (2) during an emergency period, the President might impose either quotas or a surcharge of up to fifteen percent, but not both, on the products of any country unless a product were subject to no duty under United States Tariff Schedules; ${ }^{286}$ (3) any foreign country might be exempted from the application of the surcharge; ${ }^{287}$ and (4) the President might proclaim a new balance-ofpayments emergency period only if he determined that

(1) the balance of payments (as measured by either the official reserve transactions basis or the balance on current account and long term capital) has been in deficit for four consecutive calendar quarters,

(2) the United States has suffered a serious decline in its international monetary reserves, and

(3) there is a serious threat to the international financial position of the United States. ${ }^{288}$

283 H.R. 10947, 92d Cong., Ist Sess. (1971).

284 Wall Street Journal, Nov. 5, 1971, at 4, col. 2 (Midwest ed.).

285 H.R. 10947, 92d Cong., 1st Sess. $§ 602$ (1971).

$280 I d . \S 603$.

287 Id. \& 603(c).

$288 I d . \$ \S 602(\mathrm{~b})(1)-(3)$. 
Two points may be made about the provisions. First, if the President left in force the old national emergency proclamation, he would not even have to take into account the totally discretionary limitations in imposing a new surcharge. Second, this amendment made the prior Tariff and Trade Expansion Acts, insofar as they concern the power of the President to raise tariff rates, irrelevant during a national emergency period since the President could do everything under the amendment which he could do under the Acts, and more. Thus, he could either selectively or massively retaliate without limitations on his discretion. The removal of such limitations would have been the equivalent of congressional surrender of power in an area in which, as recently as 1934, it was hotly debated whether Congress could delegate any power to the President.

When the Revenue Act reached the floor of the Senate, Sen. Alan Cranston offered an amendment to delete the entire balanceof-payments provision, ${ }^{289}$ characterizing it as "an economic Tonkin Gulf Resolution." 290 During debate, the inevitable question was raised: If the President had authority to impose the ten percent surcharge, why did he need new authority for a fifteen percent one? Supporters of the emergency provision first repeated the argument in the Senate Report that reliance on the Trading with the Enemy Act seemed inappropriate to regulate trade with allies. ${ }^{201}$ Sen. Wallace F. Bennett went somewhat further, almost revealing that there might not be authority for the surcharge as it stood. He stated that the President had been forced to rely on "completely unrelated laws" and that the Senate "should give the President specific legal authority for the future and not leave him dependent on two acts [Trading with the Enemy and the Tariff and Trade Expansion Acts] that were not intended for balance-of-payments purposes." He did not want existing statutes to be "twisted." 292 The supporters of the Cranston amendment, which failed on a 29-53 vote, 293 did not ask how "twisted" and "not intended" statutes could serve as legal justification for the surcharge since their objective was limited to opposing any new authority on the matter. ${ }^{294}$

289117 CoNG. REc. S18,733 (daily ed. Nov. 16, 1971). This amendment was cosponsored by Sen. William J. Fulbright, Sen. Mark O. Hatfield, and Sen. Charles H. Percy.

$290 \mathrm{Id}$. He added, "Trade deficits do not strike without warning like intercontinental missiles, or surreptitiously, like torpedo boats in the night." Id. at S18,734.

291 Senator Long and Sen. Wallace F. Bennett of the Finance Committee made this argument. Id. at S18,737, S18,739.

292 Id. at $\mathrm{S18,739,} \mathrm{S18,743.}$

293 Id. at $\$ 18,752$.

204 Thus, Senator Cranston seemed concerned that the President would be given too much power, id. at S18,737-38, Senator Fulbright that reducing the balance-of-payments 
With a few minor amendents, ${ }^{295}$ the balance-of-payments provision passed the Senate and was sent to the Conference Committee as part of the Revenue Act. The Chairman of the Conference Committee was Rep. Wilbur Mills, Chairman of the Ways and Means Committee. Ironically, Representative Mills was the only public official on record directly questioning the existing legal authority for the surcharge. On November 16, 1971 he had indicated that the surcharge had been imposed without "appropriate consultation with and delegation of authority from Congress." ${ }^{298}$ Necessarily realizing, therefore, that deletion of the Senate amendment would continue the absence of authority, the conferees nevertheless deleted it, explaining that " $[t]$ his amendment was not considered on its merits because of questions as to its germaneness under the House rules." 297 This meant that the House did not consider the subject matter of the balance-of-payments provision related to the tax matters contained in the bill. Not questioning the merits of the amendment also had the political advantage of avoiding criticism by protectionists of the action taken by the conferees.

Executive afterthoughts have, therefore, not produced results. They do, however, strongly reinforce the argument that the surcharge was imposed without legal authority. Only time and a possible court test will determine the consequences of such action-whether it will produce rebates for importers and consumers or be the occasion for legitimizing even further extensions of presidential power.

It is clear, however, that an administration can convince a Congress of its authority by twisting statutes. While it may be a relatively simple task to persuade protectionists and members who generally defer to

deficit would reduce incentives to cut back expenditures in Vietnam, $i d$., and Senators Javits and Hatfield that the world would be alerted to United States willingness to engage in long-term economic warfare, $i d$. at $\$ 18,734$, S18,745.

295 Senator Fulbright, for example, won Senate approval of an amendment which would have limited the grant of authority through 1973 instead of the 1976 date reported by the Senate Finance Committee. Id. at S18,752-53.

206 N.Y. Times, Nov. 17, 1971, at 65, col. 5 (city ed.). In addition to the indirect assertion of this position by Senator Bennett, a few other legislators have made similar views known. A faint hint was offered by Rep. Carl Albert, the House Speaker. N.Y. Times, Nov. 16, 1971, at 65, col. 4 (city ed.). A more direct position was taken by Sen. Norris Cotton when he offered and won Senate approval of a measure, deleted by the Conference Committee, which would have granted the President broad authority to impose quotas. Senator Cotton stated that he felt that reliance on the Trading with the Enemy and Tariff Acts was placed "arbitrarily" and that the President "might or might not be sustained by the courts in that." 117 CoNG. REc. S19,230 (daily ed. Nov. 20, 1971).

207 H.R. REP. No. 708, 92d Cong., 1st Sess. 54 (1971). The report was approved by both houses and sent to the President for signature. Members of the Senate questioned the germaneness rulings but did not comment directly on the deletion of the balance-of-payments provision. 117 CoNG. REC. S21,095-109 (daily ed. Dec. 9, 1971). 
presidential power whatever the statutory context, the silence of those members who seek to protect congressional power is most distressing. If Senator Cranston was correct in calling the balance of payments provision a new Gulf of Tonkin Resolution, it is remarkable that this time the Resolution did not become law, and yet the President pursued his policy unchallenged. ${ }^{298}$

Although in examining the surcharge it has been argued that the policy result of an extension of presidential power was unsatisfactory since the lawful policy of selective retaliation would have been preferable, surely the success or failure of the policy is not the only consideration. Even if the surcharge had succeeded in dismantling the preference system, the immeasurable cost of further disruption of the constitutional allocation of powers must be weighed in the balance.

The remarkable aspect of this examination of surcharge authority is the finding that congressional power may be eroded even where Congress has asserted its authority. Thus, despite the continuous policy judgments of Congress embedded in the tariff legislation and its refusal to validate retroactively a departure from those judgments, the President may still succeed in implementing his own policy views. If the courts abstain from preserving congressional power in a proper case, one wonders what more can be asked of Congress. Has the vigilant exercise of its tax power through legislation been futile, and is the burden now on Congress to reassert its authority once more? Even if it did so, one suspects that in the next "crisis" the President would not act much differently and that the assertion would always be one crisis too late.

\section{Conclusion}

In its attempt to obtain fundamental change in the EEC preference system, the United States has pursued a variety of policies without any significant success. Legal argumentation at the GATT has been listened to by the EEC and has even induced reply but has done little more than to focus attention on the problem. Not only is the EEC unlikely to change policies because of the persuasiveness of United States ideas, but the other member nations of GATT, as they become more involved in the EEG preference system, will probably also have little interest in supporting the United States position.

298 Of interest for the future is the fact that Pres. Proclamation 4098, 36 Fed. Reg. 24,201 (1971), which effected removal of the surcharge, did not terminate the "national emergency" proclaimed when the surcharge was declared. This may indicate that future legislation declaring the surcharge retroactively valid is a possibility. Moreover, it leaves in effect presidential access to the broad powers of the Trading with the Enemy Act. 
The United States strategy of competition, through offering its own alternative preference system to less-developed countries, has foundered essentially because of the relative unattractiveness of the United States market. Moreover, the potential of offering this market is offset by the protectionist forces in Congress and the Administration. Although the United States may eventually formulate a general preference plan, it would be surprising if less-developed countries withdrew from their trading relations with the EEC in order to participate in it.

The retaliatory policy of the surcharge did not produce trade concessions since there were other items-particularly monetary realignment-on which the United States placed higher priority. Moreover, its imposition demonstrated that the resistance of the EEC to retaliation is likely to be as great as that of France, its most resistant member. Finally, to the extent that the United States views the EEC in positive terms as related to its defense posture in Western Europe, it must stop short of imposing measures which place serious strains on EEC unity.

In the future, one course seems open-a new round of trade talks between the United States and the EEC in which reciprocal concessions are given. Two critical obstacles in the path of such an initiative may be predicted. First, such talks will by nature require United States concessions in return for alteration of the preference system, and these may be resisted by a protectionist Congress. Second, it is possible that major changes in the preference system are nonnegotiable, at least at the price the United States may be willing to pay. This possibility arises from the fact that the preference system is coordinate with the attempt of the EEC to exert influence in international affairs.

The important by-product of the surcharge was further erosion of congressional power, particularly of a power which is constitutionally and institutionaly most precious-the tax power. Congress had decided that retaliation should be on a selective basis, but the President ignored the legal status of this judgment. It is to be expected that this unchecked exercise of presidential power will be used as a precedent for still further extension in the future.

From a historical perspective, the long struggle of the United States against preferences is part of the adjustment process between the United States and Western Europe in defining relative world influence. As conflict sharpens, multilateral trade principles such as the mostfavored nation principle are being replaced by more regional and discriminatory rules, characterized by preferences. 